Specht, H., V. St-Louis, C. L. Gratto-Trevor, N. Koper, C. G. Skaggs, T. Ronningen, and T. W. Arnold. 2020. Habitat selection and nest survival in two Great Plains shorebirds. Avian Conservation and Ecology 15(1):3. https://doi.org/10.5751/ACE-01487-150103

Copyright (C) 2020 by the author(s). Published here under license by the Resilience Alliance.

Research Paper

\title{
Habitat selection and nest survival in two Great Plains shorebirds
}

Hannah Specht ${ }^{1,2}$, Véronique St-Louis ${ }^{3}$, Cheri L. Gratto-Trevor ${ }^{4}$, Nicola Koper ${ }^{5}$, Cassandra G. Skaggs ${ }^{6}$, Tait Ronningen ${ }^{7}$ and Todd W. Arnold ${ }^{1}$

${ }^{1}$ Fisheries, Wildlife and Conservation Biology, University of Minnesota-Twin Cities, St. Paul, Minnesota, USA, ${ }^{2}$ Montana Cooperative Wildlife Research Unit, University of Montana, Missoula, Montana, USA, ${ }^{3}$ Wildlife Biometrics Unit, Minnesota Department of Natural Resources, Forest Lake, Minnesota, USA, ${ }^{4}$ Prairie and Northern Wildlife Research Centre, Science and Technology Branch, Environment and Climate Change Canada, Saskatoon, Saskatchewan, Canada, ${ }^{5}$ Natural Resources Institute, University of Manitoba, Winnipeg, Manitoba, Canada, ${ }^{6}$ School of Renewable Natural Resources, Louisiana State University AgCenter, Baton Rouge, Louisiana, USA, ${ }^{7}$ U.S. Fish and Wildlife Service, Bismarck, North Dakota, USA

\begin{abstract}
As breeding populations of many grassland bird species decline, assessments of breeding habitat selection and reproductive success can provide useful insight into breeding ecology to support conservation delivery. Here, we demonstrate the use of nest location and survival data collated from 20 data contributors across the Prairie Pothole Region of the United States and Canada over a half century to examine habitat selection and nest survival of Western Willets (Tringa semipalmata inornata) and Marbled Godwits (Limosa fedoa), hereafter "willets" and "godwits." Both willets and godwits selected territories with less variation in vegetation height and topography relative to available locations. Willets selected nest sites that were flatter, closer to wetlands, and had shorter vegetation than Marbled Godwits, while godwits selected territories with greater wetland cover and shorter vegetation. Despite differences in finescale habitat selection, willets and godwits experienced similar daily nest survival rates and ecological drivers of nest survival. Nest success for the entire nest exposure period was estimated to be 0.521 (95\% credible interval: $0.39-0.65)$ for willets and $0.562(95 \%$ credible interval: $0.42-0.70)$ for godwits. Nest survival for both species increased with nest age and distance from the nest to the nearest wetland edge, while nest survival of godwits declined with conspecific breeding density. These relationships, as well as a weaker positive effect of microtine rodent abundance on nest survival, resembled drivers of upland nesting waterfowl reproductive success in the same region, which we attribute to their shared nest predators. Nest survival analyses of our collaborative dataset required substantial consideration of biases emerging from different data collection methods, ultimately reaffirming the importance of nest aging techniques in proper nest fate assignment. Analysis of compiled datasets using emerging analysis methods will continue to grow our understanding of the ecology of data sparse species.
\end{abstract}

\section{Sélection d'habitat et survie du nid chez deux oiseaux de rivage des Grandes Plaines}

RÉSUMÉ. Les populations de nombreuses espèces de prairie étant en baisse, l'examen de la sélection de l'habitat de nidification et du succès reproducteur peut apporter de nouvelles connaissances en matière d'écologie de nidification pouvant du coup contribuer à la conservation. Dans la présente étude, nous utilisons les données de localisation de nids et de survie récoltées dans la région des Cuvettes des Prairies aux États-Unis et au Canada sur une période de plus de 50 ans par 20 contributeurs, afin d'examiner la sélection d'habitat et la survie du nid chez les Chevaliers semipalmés de l'Ouest (Tringa semipalmata inornata) et les Barges marbrées (Limosa fedoa), ciaprès nommés « chevaliers » et « barges ». Tant les chevaliers que les barges ont choisi des territoires qui présentaient moins de variabilité sur le plan de la hauteur de la végétation et celui de la topographie comparativement aux endroits disponibles. Les chevaliers ont établi leur nid à des endroits plus plats, davantage près de milieux humides et où la végétation était plus courte que les sites choisis par les barges, tandis que ces dernières ont sélectionné des territoires qui comportaient une superficie plus grande de milieux humides et de la végétation plus courte. Malgré des sélections d'habitat différentes à l'échelle fine, les chevaliers et les barges avaient des taux quotidiens de survie de nids et des facteurs écologiques clés de survie des nids similaires. Le succès des nids durant la période entière d'exposition de ceux-ci a été établi à 0,521 (intervalle de confiance [I.C.] à $95 \%: 0,39-0,65$ ) pour les chevaliers et à 0.562 (I.C. à 95\%:0,42-0,70) pour les barges. La survie des nids a augmenté en fonction de leur âge et de la distance entre le nid et le bord du milieu humide le plus près chez les deux espèces, tandis que la survie des nids des barges a diminué avec la densité de conspécifiques nicheurs. Ces relations, de même que le faible effet positif de l'abondance de rongeurs de la sous-famille des microtinés sur la survie des nids, ressemblent aux facteurs liés au succès reproducteur de la sauvagine nichant sur les hautes terres de la même région, ce que nous expliquons par les prédateurs qu'ils partagent. L'analyse de survie des nids provenant de notre jeu de données issues de collaborations a demandé une attention très particulière quant aux biais inhérents aux différentes méthodes de récolte des données, nous permettant de réaffirmer l'importance des techniques d'attribution de l'âge des nids à la bonne classe de destin des nids. L'analyse de jeux de données multiples au moyen des méthodes d'analyse émergentes va contribuer à améliorer notre compréhension de l'écologie d'espèces pour lesquelles nous avons peu de données.

Key Words: alternate prey; Marbled Godwit; mark-recapture; nest age; nest-site selection; nest survival; Willet 


\section{INTRODUCTION}

Understanding habitat selection and its influence on survival and reproduction is important to support effective habitat conservation and to understand ecological pressures affecting population growth. In birds, the selection of nesting sites has long been considered to indicate habitat that maximizes fitness outcomes (Orians and Wittenberger 1991), which are driven by nest failures caused by predation (Clark and Shutler 1999), environmental exposure (Reid et al. 2002), disturbance (Galbraith 1988), or their interactions. However, there is not always clear evidence that habitat features selected by nesting birds confer higher probability of nesting success (Clark and Shutler 1999, Chalfoun and Martin 2007), and such instances may indicate presence of ecological or evolutionary traps (Devries et al. 2018, Zhao et al. 2019). Regardless, evaluating habitat selection and reproductive success can provide insight into complex ecological relationships between predators and prey (Lamarre et al. 2017) and presents opportunities to better inform policy and management (Reynolds et al. 2006).

Nest success, the probability that $\geq 1$ egg hatches (precocial species) or $\geq 1$ nestling fledges (altricial species), is a common metric of reproductive performance in birds, but acquiring data to evaluate drivers of nest success requires locating and monitoring large numbers of nests. Thus, data for nest success often come from locally intensive studies conducted over a few years, limiting the temporal and spatial scope of inference (Winter et al. 2005). Identifying patterns of habitat selection and recruitment that represent the species throughout substantial portions of its breeding range and across multiple generations of breeders is best achieved using data with broad spatial and temporal representation. Nesting data to relate habitat use to reproductive success can be particularly challenging to acquire for low-density, cryptic species with large breeding home ranges, such as upland-nesting Western Willets (Tringa semipalmata inornata) and Marbled Godwits (Limosa fedoa) in the Northern Great Plains (Niemuth and Solberg 2003, Garvey et al. 2013), hereafter "willets" and "godwits." Willets and godwits are grassland-nesting migratory shorebirds most often observed along shallow wetland edges, which they use for feeding and brood rearing. Primary breeding populations of both species in the Northern Great Plains have declined since the mid-1900s (19672015; Smith et al. 2019, Pardieck et al. 2019). Declines have presumably been driven by conversion of grassland and wetland habitat used during the breeding season to row crop agriculture (Brockway et al. 2002, Stephens et al. 2008, Johnston 2013), prompting interest in understanding their breeding ecology as it relates to demographic performance. Occurrence and abundance data, typically derived from roadside surveys, provide insight into broad patterns of settlement across the species breeding range, indicating that both species settle in areas with greater wetland and grassland cover (Ryan et al. 1984, Ryan and Renken 1987; N. Niemuth, personal communication). However, these survey data do not provide insight into finer scale habitat features important to nesting birds because nonincubating birds can be detected in surveys up to 2.5 kilometers away from their nests (B. Olsen, personal communication).

Nests of willets and godwits occur at low densities and are difficult to find because eggs are cryptic and incubating birds only flush from nests at very short distances. As a result, few studies have acquired sufficient nesting data to compare and contrast patterns of habitat selection and nest success for each species and the differences between them (Higgins et al. 1979, Garvey et al. 2013, but see Gratto-Trevor 2006). To the contrary, investigators have often pooled nesting data from willets, godwits, and other uplandnesting shorebirds because of low sample sizes (e.g., McMaster et al. 2005, Ludlow and Davis 2018). Studies based on small sample sizes have produced point estimates of nest success that vary widely (willet: 3-70\%, godwit: 11-70\%; Higgins et al. 1979, Kantrud and Higgins 1992, Gratto-Trevor 2000, Lowther et al. 2001) but have had little capacity to identify ecological drivers of that variation or explore differences between the two species.

Increasingly, ecologists compile data from multiple sources and analyze them together, improving insight into species ecology and opportunities for conservation (Weiser et al. 2018, Saunders et al. 2019). We compiled nest records from $>20$ different nesting studies conducted throughout the Northern Great Plains to examine nesting phenology, breeding habitat selection, and nest survival for willets and godwits, allowing us to directly compare habitat use and nest survival between these two co-occurring species.

Field observations and surveys that identify broad patterns of settlement highlight willets' use of grazed pasture and seasonal and temporary wetlands, while godwits have been observed more often in ungrazed grassland, cropland, and along alkali lakes and shallow wetland edges (Ryan et al. 1984, Ryan and Renken 1987, Kantrud and Higgins 1992). To understand how vegetation cover and wetland types influence nest-site selection and nest survival, we quantified wetland, vegetation, and topographic characteristics at nest sites using remotely sensed variables, evaluating selection by each species relative to available locations in a discrete choice modeling framework (Cooper and Millspaugh 1999). Because selection of nest sites with certain characteristics can reduce cues to nest predators (Martin 1993), we hypothesized that both species would select nest sites farther from wetland edges, because waterfowl nests near wetland edges in the same landscape experience greater depredation rates (Phillips et al. 2003, Horn et al. 2005, Thompson et al. 2012). Additionally, we hypothesized both species would select for more homogenous vegetation structure at nest sites, avoiding portions of grassland with greater shrub cover. We hypothesized that willets would nest in areas with shorter vegetation and less wetland cover, with the nearest wetland being smaller relative to godwits, based on observations of willet occurrence in grazed grassland and observations of godwit broods at larger wetlands (Ryan et al. 1984, Ryan and Renken 1987, Kantrud and Higgins 1992).

We also examined the effects of nesting phenology, predator behavior, density dependence, and habitat characteristics on nest survival of both species. Nests vulnerable to predation may be more likely to experience early depredation, and incubating pairs may go to greater lengths to defend nests that are closer to hatch (Smith and Wilson 2010), leading us to hypothesize greater daily nest survival at older nests. Nest survival may also change with initiation date, reflecting possible consequences of growing vegetation and shifts in predator behavior with prey availability (Smith and Wilson 2010, Smith et al. 2018). Arctic-nesting shorebirds experience lower nest predation risk at higher latitudes (McKinnon et al. 2010), an effect that we considered though did 
not expect to find, given the similarities in described predator communities throughout the study region (Sargeant et al. 1993).

We hypothesized that willets and godwits would experience lower nest survival near wetland edges and higher nest survival during Short-eared Owl (Asio flammeus) irruptions. Upland-nesting waterfowl, with which upland-nesting shorebirds share a nest predator community, e.g., striped skunks (Mephitis mephitis), red fox (Vulpes vulpes), coyote (Canis latrans), and gulls (Larus sp.; Johnson et al. 1989, Kantrud and Higgins 1992), experience lower daily nest survival at nests located near wetland edges because of increased predator foraging behavior along edges (Phillips et al. 2003). Additionally, upland-nesting waterfowl and arctic shorebirds exhibit higher recruitment in locations and years with high microtine rodent abundance, driven by nest predators' satiation on abundant microtine rodents (Brook et al. 2008, McKinnon et al. 2014); in the plains, rodent irruptions can be indicated by irruptions of specialist predator Short-eared Owls (Poulin et al. 2001, Specht and Arnold 2018).

Optimal foraging theory predicts that higher active nest densities decrease the probability that any individual nest will be encountered by a generalist nest predator (Schmidt 1999). We hypothesized that willet and godwit nest survival would benefit from higher nest densities, assuming those of greatest relevance were likely to be upland-nesting waterfowl given their greater abundance. We also considered conspecific density, hypothesizing no effect on nest survival given low nesting densities of both species; however, if suitable nest sites were sufficiently limited, as could be the case in the highest density parts of each species range, individuals nesting in suboptimal habitat could experience lower nest survival (Devries et al. 2018). To this end, we hypothesized lower nest survival in cropland relative to grassland and hay land cover types. Finally, we considered the effect of vegetation and topography variables included in nest site selection models; we hypothesized greater nest survival in shorter vegetation and flatter areas given the tendency for incubating adults of both species to resist flushing off of nests until absolutely necessary, a behavior potentially aided by good visibility provided in shorter vegetation and flatter locations.

\section{METHODS}

\section{Study area and data collection}

Nest records for Western Willets and Marbled Godwits from 1970 to 2017 were compiled from 20 independent data contributors (Table A.11) from an area covering Alberta, Saskatchewan, Manitoba, North Dakota, and South Dakota (Fig. 1). This region of the Northern Great Plains is characterized by native mixed grass prairie, row crop agriculture, and densities of pothole wetlands that can reach up to $25 \mathrm{basins} / \mathrm{km}^{2}$. Although most agricultural conversion took place early in the 20th century (Waisanen and Bliss 2002), conversion of grasslands and wetlands to row crops continues (Johnston 2013). Studies contributing nest records were conducted on a mix of publicly managed grasslands (e.g., U.S. Fish and Wildlife National Wildlife Refuges, Alberta Fish and Game Association) and privately managed grasslands and cropland (e.g., Ducks Unlimited, private landowners).
Fig. 1. Relative breeding season population density of Marbled Godwits, Limosa fedoa (A) and Western Willets, Tringa semipalmata inornata (B) in the prairies based on North American Breeding Bird Survey Data (USGS) where density is represented as the estimated number of birds per 40-km survey route. Black dots in each figure represent nests from each species. More Marbled Godwit nests than Western Willet nests were located in areas where godwit population density is relatively higher than willets $(\mathrm{C}$; green shading and blackoutlined green cells) and visa-versa (C; blue shading and blackoutlined blue cells).
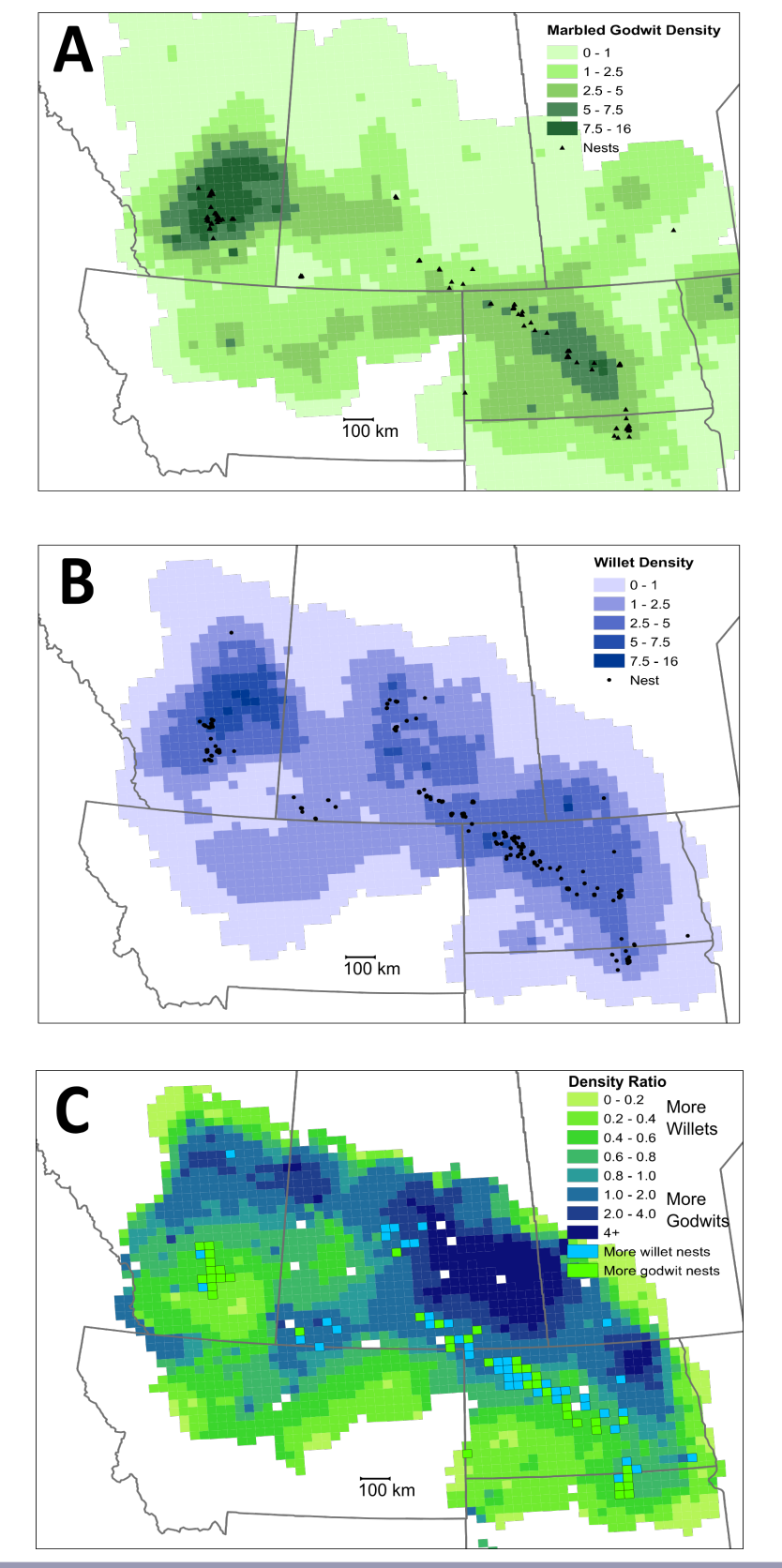
Nearly all nests $(99 \%, 1053 / 1063)$ were located using vehicletowed cable or chain drags, hand-pulled rope drags, or by striking thicker vegetation with willow switches (e.g., Greenwood et al. 1995, Emery et al. 2005, but see Appendix 1 for full table of related manuscripts) during area searches, while remaining nests were located by incidental encounter. Designated study areas were searched on regular intervals and nest searching often ran from late-April to mid-June. Former technicians from these studies report thorough searches of wetland edges and brushy areas (personal communication). All studies recorded nest data for both willets and godwits and nest locations were recorded with global positioning system (GPS) coordinates or by hand on aerial image maps (Fig. 2). We assumed $30 \mathrm{~m}$ precision for nest locations based on map detail relative to landscape features and accounts from former technicians of using maps to relocate nests. Nest cover type, e.g., grassland, cropland, or hay field, was reported by studies that searched for nests in multiple cover types and could be inferred from study area descriptions in most other cases.

Fig. 2. We compiled Western Willet (Tringa semipalmata inornata) and Marbled Godwit (Limosa fedoa) nest data from existing databases, as well as nest cards (a) and corresponding maps (b) such as this example from 1981 at Kulm Study Area (research conducted by Northern Prairie Wildlife Research Center, U.S. Geological Survey, previously the U.S. National Biological Survey). Willet and godwit nest records were subsequently georeferenced (c).

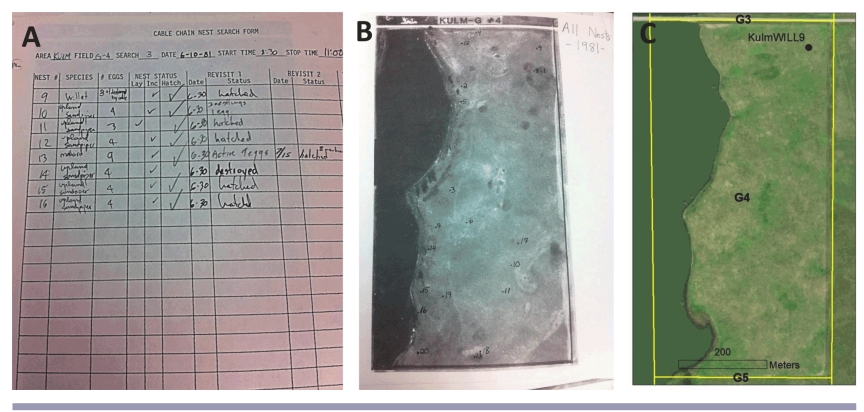

Most records (87\%) with nest survival data sufficient for analysis, i.e., at least two visits to a known-location nest with incubation status (632 total), were derived from studies that used incubationage and nest-fate assessments specific to shorebird nests (e.g., Garvey et al. 2013). However, when nest data collection protocols were not documented, we assumed they followed methods similar to the waterfowl nest monitoring that produced them, based on use of identical data forms and personal communication (e.g., Klett et al. 1986).

\section{How well does the compiled dataset represent the study species?}

We sought to understand how well study sites within our dataset represented land cover and relative population densities of Western Willets and Marbled Godwits throughout the breeding range of each species within the Northern Great Plains. Using data from the North American Land Cover dataset (North American Land Change Monitoring System, Commission for Environmental Cooperation 2016), we assessed proportional grassland and wetland cover in areas where nest records occurred and compared this to range-wide metrics using Welch's t-tests. To determine whether study sites represented the range-wide nesting habitats of both species, we compared the relative density of willet and godwit nests at study sites to the relative breeding density predicted from North American Breeding Bird Survey data (BBS; Pardieck et al. 2019). The BBS estimates relative bird density using a fishnet grid with side length $21.5 \mathrm{~km}$ (https://www.mbr-pwrc. usgs.gov/bbs/ramapin 15.html); we conducted our analyses using this existing grid. We defined the breeding ranges for each species as BBS cells with predicted densities of greater than $1 \mathrm{bird} / 40.23$ kilometers (representing the number of willets or godwits that could be seen in $\sim 40$ kilometers of roadside bird watching, based on 2011-2015 data). We compared the relative density (willet: godwit density) from BBS data to the ratio of nests (willet:godwit nests) detected within cells where study sites occurred to evaluate whether there were clear, species-specific biases in nest searching methods or locations, as may be indicated if the nest ratio diverged greatly from the BBS occurrence ratio. We believe that relative abundance ratios from BBS data reflect relative abundance for the study period because roadside survey detection probabilities are similar between species (Specht 2018), population changes within districts of the study area are similar between species (Pardieck et al. 2019), and because the BBS abundance indices reflect a time period that encompasses most of the period of our nest data (1967-2015).

\section{When does nesting occur?}

We used estimated nest initiation dates to characterize nesting chronologies for each species. Additionally, we used linear and mixed effect linear models to test the hypotheses that (1) nest initiation has shifted earlier in the season over the study period, as might be predicted by warming early-season temperatures due to climate change (McCarty 2001, Kwon et al. 2018) and (2) nests are initiated later at higher latitudes within years (model details in Appendix 1).

\section{Do species exhibit selection for breeding habitat characteristics?}

We compared habitat characteristics around nest locations to those of nearby areas that we presumed were available but not selected by each nesting pair for that nesting attempt. We examined habitat characteristics immediately around nest locations to understand the importance of local habitat features to nest placement, assuming that characteristics of this area may influence nest survival as driven by the probability that a nest is encountered by a nest predator.

We compared characteristics of nest sites to those at five, nonwetland points randomly selected from within an area that approximated the size of observed breeding-season space-use specific to the location of that nest; this was defined as a circular area centered on the nest for each species (godwit: 530-m radius corresponding to 88 ha area of breeding season space use; Ryan et al. 1984; willet: 375 -m radius corresponding to a 44.3 ha; Ryan and Renken 1987). We considered available nesting habitat to exclude wetlands, as defined by wetland databases (e.g., National Wetland Inventory, but see Table 1 for further description of wetland data); defining available habitat to exclude wetlands is reasonable because, although both species will nest close to wetland edges, only one nest within our dataset was classified as 
Avian Conservation and Ecology 15(1): 3

http://www.ace-eco.org/vol15/iss1/art3/

Table 1. Covariates included in models examining nest $(\mathrm{N})$ selection and broader (B) habitat use as well as nest survival (S), organized by the analyses in which they are included. All variables derived from remotely sensed data were included in analyses at scales similar to or coarser than the assumed error in nest location.

\begin{tabular}{|c|c|c|c|c|}
\hline Covariate & Analysis & Data Source & Resolution & Description \& Preparation \\
\hline Vegetation height & $\mathrm{N}, \mathrm{B}, \mathrm{S}$ & $\begin{array}{l}\text { LandSat } 7 \text { Band } 4 \text {, } \\
\text { USFWS Waterfowl } \\
\text { Breeding Pair and Habitat } \\
\text { Survey Pond Count Data }\end{array}$ & $30-\mathrm{m}$ raster & $\begin{array}{l}\text { The mean height of vegetation, estimated using reverse near infrared following the } \\
\text { methods provided in Figure } 7 \text { of Marsett et al. } 2006 \text {. We selected LandSat } \\
\text { images with the least cloud cover for each part of the study area from mid-May } \\
\text { (close to mean nest initiation date) in a subset of years }(2001,2003,2005,2012) \\
\text { that approximated mean hydrologic conditions for the study period }(1970-2016) \text {. }\end{array}$ \\
\hline Vegetation heterogeneity & $\mathrm{N}, \mathrm{B}, \mathrm{S}$ & $\begin{array}{l}\text { LandSat } 7 \text { Band } 4 \text {, } \\
\text { USFWS Waterfowl } \\
\text { Breeding Pair and Habitat } \\
\text { Survey Pond Count Data }\end{array}$ & $30-\mathrm{m}$ raster & $\begin{array}{l}\text { The standard deviation of "vegetation height" (as measured above) within a 50-m } \\
\text { radius of a nest or availability point or at a "broader" breeding scale. }\end{array}$ \\
\hline Topographic variation & $\mathrm{N}, \mathrm{B}, \mathrm{S}$ & $\begin{array}{l}\text { Digital Elevation Model } \\
\text { Data (Canada and U.S.) }\end{array}$ & $30-\mathrm{m}$ raster & $\begin{array}{l}\text { The standard deviation of the } 30 \mathrm{~m} \text { merged digital elevation model calculated } \\
\text { from Canadian and American Digital Elevation Model Datasets. }\end{array}$ \\
\hline Wetland proximity & $\mathrm{N}, \mathrm{S}$ & $\begin{array}{l}\text { National Wetland } \\
\text { Inventory (U.S.), } \\
\text { Canadian Wetland } \\
\text { Inventory (AB) and Ducks } \\
\text { Unlimited Canada (AB, } \\
\text { SK, MB) }\end{array}$ & meters & $\begin{array}{l}\text { Distance from nest location to the edge of the nearest wetland using wetland } \\
\text { polygon data. Divided by proportional inundation ("inundated wetland density } \\
\text { index," above) for the respective region and year to adjust for hydrologic } \\
\text { conditions (such that in dry years, wetland edges are further away proportional to } \\
\text { variation across the time span of the study). }\end{array}$ \\
\hline Area of nearest wetland & $\mathrm{N}$ & $\begin{array}{l}\text { National Wetland } \\
\text { Inventory (U.S.), } \\
\text { Canadian Wetland } \\
\text { Inventory (AB) and Ducks } \\
\text { Unlimited Canada (AB, } \\
\text { SK, MB) }\end{array}$ & hectares & Area in ha of wetland nearest to nest. \\
\hline Grassland cover & $\mathrm{B}, \mathrm{S}$ & $\begin{array}{l}\text { North American Land } \\
\text { Cover Dataset } 2010\end{array}$ & $30-\mathrm{m}$ raster & The proportion in grassland cover. \\
\hline $\begin{array}{l}\text { Wetland } \\
\text { Cover }\end{array}$ & $\mathrm{B}$ & $\begin{array}{l}\text { North American Land } \\
\text { Cover Dataset } 2010\end{array}$ & $30-\mathrm{m}$ raster & $\begin{array}{l}\text { Proportion of area in wetland cover. Multiplied by proportional inundation } \\
\text { (inundated wetland density index, above) for the respective region and year to } \\
\text { adjust for hydrologic conditions (such that in drier years, there is lower wetland } \\
\text { cover). }\end{array}$ \\
\hline Nest Cover Type & $\mathrm{S}$ & Provided in Dataset & at nest & \\
\hline $\begin{array}{l}\text { Inundated wetland } \\
\text { density index }\end{array}$ & $\mathrm{S}$ & $\begin{array}{l}\text { USFWS Waterfowl } \\
\text { Breeding Pair and Habitat } \\
\text { Survey Pond Count Data }\end{array}$ & Stratum-year & $\begin{array}{l}\text { Proportional density }(0-1) \text { of inundated wetland basins relative to the maximum } \\
\text { observed in the respective region over the period of the dataset }(1970-2017) \text { for } \\
\text { the survey stratum and year that corresponded to each nest record. }\end{array}$ \\
\hline Alternate prey index & $\mathrm{S}$ & $\begin{array}{l}\text { North American Breeding } \\
\text { Bird Survey }\end{array}$ & Stratum-year & $\begin{array}{l}\text { Short-eared Owl (Asio flammeus) density (birds per survey route) providing an } \\
\text { index of vole abundance (Specht and Arnold 2018). Data were aggregated to } \\
\text { USFWS Waterfowl Breeding Pair and Habitat Survey stratum to better identify } \\
\text { regional population irruptions for a specific year. }\end{array}$ \\
\hline $\begin{array}{l}\text { Western Willet (Tringa } \\
\text { semipalmata inornata) or } \\
\text { Marbled Godwit } \\
\text { (Limosa fedoa) } \\
\text { population density }\end{array}$ & $\mathrm{S}$ & $\begin{array}{l}\text { North American Breeding } \\
\text { Bird Survey }\end{array}$ & $21.5-\mathrm{km}$ raster & $\begin{array}{l}\text { Estimated index of population density (birds per survey route) for the species } \\
\text { corresponding to each nest record, static across years. }\end{array}$ \\
\hline $\begin{array}{l}\text { Waterfowl nesting } \\
\text { density index }\end{array}$ & $\mathrm{S}$ & $\begin{array}{l}\text { USFWS Waterfowl } \\
\text { Breeding Pair and Habitat } \\
\text { Survey }\end{array}$ & Stratum-year & Density of dabbling duck breeding pairs as an index of upland nest density. \\
\hline Nest age & $\mathrm{S}$ & Provided in dataset & Nest & Derived from nest record as the age of the nest when first encountered. \\
\hline Nest initiation date & $\mathrm{S}$ & Provided in dataset & Nest & $\begin{array}{l}\text { Derived from nest age and observation data information provided in nest records. } \\
\text { Included in analysis as a quadratic effect in analysis. Day } 1 \text { is the earliest nest } \\
\text { initiation contained in the dataset ( } 20 \text { April). }\end{array}$ \\
\hline Latitude & $\mathrm{S}$ & Provided in dataset & $\begin{array}{c}\text { Decimal } \\
\text { degrees }\end{array}$ & Included to account for spatial gradients in phenology. \\
\hline Study plot & $\mathrm{S}$ & Provided in dataset & $\begin{array}{l}\text { Random } \\
\text { Effect }\end{array}$ & $\begin{array}{l}\text { Study sites identified by data contributors and using geographic information } \\
\text { system. Included to account for potentially distinct data collection methods across } \\
\text { research groups and field crews. }\end{array}$ \\
\hline Year & $\mathrm{S}$ & Provided in dataset & $\begin{array}{l}\text { Random } \\
\text { Effect }\end{array}$ & $\begin{array}{l}\text { Nest record year, included as a factorial random effect with study plot to account } \\
\text { for similarities in nest survival within years (at sites) due to ecology or } \\
\text { methodology. }\end{array}$ \\
\hline
\end{tabular}

occurring within the boundary of a wetland. Choice sets with five available points have been found to be sufficient for examining selection with discrete choice designs (Fig. 3; McFadden 1978, Cooper and Millspaugh 1999, Baasch et al. 2010). Case-specific available points, unused by the breeding pair for that specific nesting attempt, could have been used by another breeding pair or by the same pair in another nesting attempt. At each nest site and its corresponding availability sites, we quantified proximity to the nearest wetland edge, wetland area within $50 \mathrm{~m}$, topographic variability within $50 \mathrm{~m}$, vegetation height, and heterogeneity in vegetation height within $50 \mathrm{~m}$ (Table 1). 
Fig. 3. We evaluated selection for specific habitat characteristics with discrete choice use-availability models based on the location of each nest (asterisk) relative to other nonwetland locations available (orange dots) within a circular area that approximated the size of a broader area utilized for breeding activities (blue circle; Marbled Godwits (Limosa fedoa): 530-m radius and Western Willets (Tringa semipalmata inornata): 375 $\mathrm{m})$ for that species. Available points (orange dots) were not used by that breeding pair in that nesting attempt, but could have been used by another breeding pair or by that same breeding pair in a different nesting attempt.

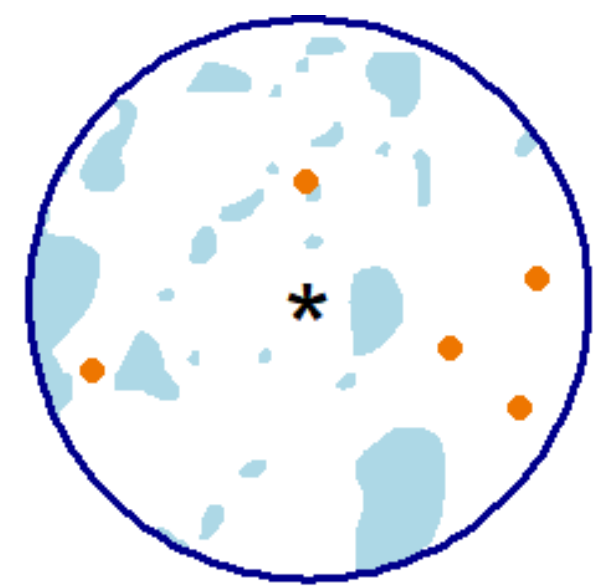

All habitat variables were derived from remotely sensed data and reflected characteristics of the landscape we believe to be relatively stable over time. We derived an index of vegetation height that could be assessed across use and availability locations from a subset of the Landsat Enhanced Thematic Mapper 7 ETM+ years where hydrologic conditions were closest to the mean regional hydrologic conditions for the 1970-2016 study period (determined using pond count data from U.S. Fish and Wildlife Service, Waterfowl Breeding Pair and Habitat Suitability data); mixed-grass prairie vegetation structure varies more across space than over time owing to complimentary productivity of wet and dry adapted species (La Pierre et al. 2016). Wetland conditions are highly variable among years and across the Northern Great Plains region, shaping patterns of wetland-based food resource availability and nest density via waterfowl settlement (Leitch and Kaminski 1985, de Szalay et al. 2003). We used relative wetland inundation (wetland basins inundated in a given year and survey stratum relative to the maximum observed 1970-2017, see Table 1; Waterfowl Breeding Pair and Habitat Survey) as an annual adjustment factor for wetland cover and proximity variables.

We fit random-effect discrete choice models (Cooper and Millspaugh 1999) using a Bayesian approach to estimate the probability that a Willet or Marbled Godwit would select a site for nesting. We fit an a priori model with five covariates for each species after considering hypotheses and the degrees of freedom available (Giudice et al. 2012, Harrell 2015). The continuous covariates in each species' model were normalized by their means and standard deviations and were included based on low collinearity ( $\max$ observed $\mathrm{R}^{2} \leq 0.13$ ). We modeled covariate coefficients as case-specific random effects to allow inference related to population-level selection while accounting for similarities within case sets associated with each nest record. We used JAGS software via the jagsUI package (Plummer 2003, Kellner 2019) implemented in R (R Core Team 2018). Models were run with three chains and a thinning rate of 2 with 20,000 iterations, a 100 iteration burn-in, and 2000 iteration adaptation period, resulting in 29,850 posterior samples. We examined values and trace plots to check for convergence and evaluated model fit using Bayesian p-values (Kéry and Schaub 2012). We interpreted posterior distributions as providing probabilistic information about the true values of parameters or coefficients; when very little of the posterior mass overlaps zero $(<5 \%)$, we interpreted the sign of a coefficient to be informative. We interpreted cases where $<15 \%$ of the mass overlaps zero to be indicative of a possible relationship. The magnitude of the coefficients provide insight into the relative importance of selection for habitat components as we have quantified them, but we note that these relationships do not necessarily apply to these same habitat characteristics as might be quantified from direct field measurements.

\section{Do willets and godwits differ in their selection for breeding habitat characteristics?}

In addition to evaluating selection by each species relative to available habitat, we directly compared characteristics of nest sites used by godwits relative to willets, as well as characteristics of broader areas around nests. We assumed that the area within a few hundred meters of a nest provides resources for brood rearing in the days immediately after hatch but before hatchlings are able to cover large distances. We hypothesized that use for both nesting and proximate habitat available for brood rearing differs between the study species. We used 375-m radius circles centered on nest locations (corresponding to the size of an area used by Willets during breeding activities, but applied to both species; Ryan and Renken 1987) in order to directly compare habitat characteristics at this broader, brood-rearing scale. Within each broader circle, we quantified wetland and grassland area, vegetation height, vegetation height heterogeneity, and topographic variability (Table 1). At this scale, we could not confidently characterize available habitat to support selection analyses because available areas within a several-kilometer area extended beyond study area boundaries, for which we did not have access to land-use history. Thus, we did not assess habitat selection by each species at this larger scale.

We used a Bayesian implementation of a generalized mixed effect model accounting for study-site similarities to compare nest-sites and broader areas between the species (model details in Appendix 1). Additionally, we used field-measured vegetation data associated with 222 nest records to examine differences in vegetation height between the nest sites of willets and godwits, using a generalized linear mixed effects model accounting for differences in measurement methods amongst studies.

Using a subset of nests that occurred in areas with data on wetland permanence (395 nests in North and South Dakota, permanence defined as temporary, seasonal, semipermanent, or permanent 
per Cowardin et al. 1979), we tested the hypothesis that willets and godwits nested near different wetland types ( $\chi^{2}$ test). Additionally, we tested whether godwits nest in cropland more often than willets ( $\chi^{2}$ test) using land cover data reported in nest records.

\section{How does data quality affect nest survival estimates?}

Despite similarities in life history between upland-nesting shorebirds and waterfowl that allowed collection of shorebird nest data as part of waterfowl nesting studies, shorebird nest fate and egg developmental age are assessed with different methods than waterfowl nests. Prior to the development of shorebird-specific nest monitoring methods, possible application of waterfowl nest monitoring protocols to shorebird nests could have resulted in biases in nest fate assessment that may have affected nest survival estimates. A subset of 745 nest records contained data potentially relevant to nest survival estimation (at least two visits to a nest with a nest status recorded for each visit), within which 653 nests contained location information that could allow us to examine the relationships between daily nest survival and characteristics of habitat and community dynamics. We aimed to include data in our nest survival analyses that represented as much spatial and temporal variation as possible, while seeking to avoid biases introduced by the evolution of nest survival monitoring protocols by testing assumptions and potential constraints.

We reasoned that nest fate could be confidently determined if final nest fate was assessed around the expected hatch date because nests that terminated before the expected hatch date could reasonably be determined to have failed. Shorebird eggshells are opaque and not easily aged using candling methods employed in waterfowl nest studies. Until egg flotation methods were adopted (Liebezeit et al. 2007), shorebird nests could not be reliably aged to predict expected hatch date, unless they were found during the laying stage. Inclusion of unaged nests in nest survival analyses could influence our understanding of nest survival dynamics if daily nest survival rate (DSR) changed over the course of the season, and if these nests were only encountered at the beginning of the season. Alternatively, nest age could also be estimated if a nest was encountered or visited during hatch; including these nests in analyses could positively bias our estimates of nest survival because these nests all survived until hatch. We hypothesized that nests of known age from these studies that occurred before flotation methods were adopted would result from a different distribution of nest discovery across the season, reflecting their early encounter in the nesting cycle. We verified that age and Julian date at encounter for known-age nests from earlier studies did not come from an obviously different distribution than data from studies that employed shorebird nest-aging techniques using visual inspection of distributions and Welch's t-tests (Ruxton 2006). Additional bias could have been introduced by cases where nest fate was evaluated long after the nest was depredated or hatched, particularly before shorebird-specific nest fate indicators had been described; successful shorebird nests often have small eggshell fragments, but never egg membranes, which are a typical sign of successful hatch for duck nests (Klett et al. 1986, Mabee 1997, Gratto-Trevor 2000, Lowther et al. 2001, Mabee et al. 2006). Incorrect nest fate assessment based on waterfowl nest fate guidelines could have resulted in possible negative bias in fate assessment of unaged shorebird nests from older waterfowl studies.

We examined how delaying nest fate assessment for an increasing number of days after the expected hatch date or previous visit affected DSR estimates by comparing different subsets of data, e.g., nest fate assessed within $\leq 14$ days of expected hatch date, to a reference dataset defined by methods standard in other shorebird studies (e.g., Liebezeit et al. 2009). The reference dataset included nests that were monitored $\leq 7$ days after the expected hatch date. Nests that were aged but monitored outside of this window had their survival histories "right-truncated" to include only nest monitoring activity up to the expected hatch date; these nests were equally likely to have failed as other monitored nests and excluding them based on surviving longer would introduce negative bias to the data (Stanley 2004). With this approach we could not discern whether observed differences in DSR estimates were driven by differences in nest monitoring methods or by variation in nest survival, though we conservatively presumed differences to be driven by methodology. Across considered data subsets, DSR estimates for at least one species were further than one standard error from those produced by the reference dataset (Table A1.2). We therefore included only nests of known age in further nest survival analyses.

\section{How do habitat characteristics and temporal variation in predator and prey communities influence nest survival?}

We examined ecological relationships to daily nest survival, considering variables related to habitat characteristics (e.g., vegetation, wetlands, topography), dynamics of alternate prey for nest predators (e.g., indices of duck nest and rodent densities), timing, and location (e.g., nest age, latitude; Table 1). We specified covariate effects related to predator behavior as shared effects across willet and godwit nests, but allowed species-specific variation in nest survival relationships for habitat variables where habitat selection in the nest-site selection model was species specific. To account for variation in wetland density across different years, we multiplied all wetland variables by a wetland inundation index specific to each year and region (Table 1); this correction factor increased distance to the nearest wetland edge and decreased wetland cover in years that were dry by a proportion relative to full inundation. We included a variable for grass cover within $1000 \mathrm{~m}$ of nest locations, given positive correlations between grass cover and waterfowl nest survival (Table 1; Stephens et al. 2005), as well as an indicator variable specifying whether the nest occurred in grassland (as opposed to hayland or cropland; Table 1). Clutch initiation date was determined based on nest age and was included in the nest survival model, reflecting possible consequences of growing vegetation and shifts in predator behavior with prey availability (Smith and Wilson 2010, Smith et al. 2018). Finally, we included random effects for study site and year to account for unmodeled variation in data collection and anomalous conditions across regions and years.

We modeled DSR as a Bernoulli process where the likelihood consists of the product of two variable-length vectors of daily survival rates for each nest: (1) the "initial" monitored period between the day the nest was found and when it was last known active and (2) the "ultimate" uncertain period between when the 
nest was last known active and when fate was determined (model code in Appendix 1; Specht 2018). We ensured that our model produced reliable estimates by applying it to data from Shaffer's (2004) analysis, recovering the same daily survival rates to the fourth decimal place, implemented in R (R Core Team 2018). We included random effects for study plot and year to account for variation that could be attributed to data collection or unmeasured conditions. To estimate period nest success for our study species, we assumed that the average incubation period was 25 days for willets and 24 days for godwits, that the laying period for a typical four-egg nest would take five days and that there was a least one day of incubation prior to clutch completion (GrattoTrevor 2000, Lowther et al. 2001). As such, we used nest exposure periods of 29 days for willets and 28 days for godwits.

We modeled the relationships between variables and DSR using a logit link:

$$
\operatorname{logit}\left(D S R_{j k s}\right)=\beta_{0 j k}+\beta_{1 S} X_{1}+\beta_{2} X_{2}
$$

where $D S R_{j k s}$ is the daily survival rate for species $s$ in year $j$ and study plot $k ; \beta_{0 j k}$ is a year- and study plot-specific intercept; $\beta_{I S}$ represents a vector of five species-specific coefficients while $\beta_{2}$ is a vector of nine coefficients shared across both species, with $\boldsymbol{X}_{\boldsymbol{I}}$ and $\boldsymbol{X}_{2}$ representing matrices of respective covariates (see included variables in Table 1). We assumed identical regression relationships for "initial" and "ultimate" periods in the flexible model described above, which is particularly appropriate for our precocial species, where nest survival does not include a nestling period. As with habitat selection analyses, variables were normalized by their means and standard deviations across studies, and all pair-wise correlation coefficients of included variables $\left(\mathrm{r}^{2}\right)$ were $<0.35$. Mean $D S R$ was drawn from a uniform $(0-1)$ prior and each coefficient from a normal distribution using a vague prior $($ mean $=0, \tau=0.03)$. We used Bayesian Markov chain Monte Carlo (MCMC) analysis with JAGS (Plummer 2003) in Program $\mathrm{R}$ (Version 3·2 3; R Core Team 2018; see code in Appendix 1). We implemented 3 MCMC chains in Bayesian models with 25,000 iterations, including burn-in and adapt periods of 2000 and 5000 iterations, respectively, and a thinning rate of 2, yielding 34,500 samples for each posterior distribution. We assessed convergence of our single, a priori model by examining trace plots and values (Gelman and Rubin 1992).

\section{RESULTS}

\section{How well does the compiled dataset represent the study species?}

Most nests occurred in native grasslands that were not converted to other land use types between the year of nest data collection and 2015, reflecting study areas occurring on protected and working grasslands that have maintained their cover characteristics ( $88 \%$ of nest records that included location data). Unsurprisingly, areas where study sites occurred had significantly greater grassland cover than was representative of the range of either species (Table 2, rows a-b). Study areas also had greater wetland cover than representative of the willet range (Table 2, cd).
Within parts of the species ranges that contained study sites, relatively more willet nests than godwit nests were encountered in areas with relatively higher Willet pair density (57\% of cells where at least one nest was encountered; Fig. 1). Although most instances of disagreement in relative density, e.g., more willet nests found in an area with higher godwit density, represented study sites in which the nest sample size was small (e.g., $<5$ nests), there were some outliers from large study sites in central North Dakota (e.g., $>15$ nests).

\section{When does nesting occur?}

Mean nest initiation date was similar for godwits and willets (willet mean: 17 May, $n=424$, godwit mean: 16 May, $n=208$ ). The $90 \%$ range of nest initiation dates was similar between the two species (30 days, willets: 14 May-13 June, godwits: 12 May11 June); willets exhibited wider full range of nest initiation dates reflecting a larger sample of nests (willet: 20 April-19 June; godwit: 28 April-11 June). Initiation was not related to year nor latitude for either species, nor was there evidence that nests were initiated later at higher latitudes within years (Table 2, e).

\section{Do species exhibit selection for breeding habitat characteristics?}

We modeled resource selection using data from 608 willet nests and 304 godwit nests. Nest site selection models exhibited Bayesian p-values of 0.11 and 0.35 for willets and godwits, respectively; we therefore assumed sufficient fit to inform our broad questions, albeit better for godwits ( $p$-values near 0 or 1 indicate lack of fit). Willets selected nesting sites with vegetation that exhibited less height variation than random sites (Fig. 4a; Table 2, f), whereas godwits selected nesting sites associated with flatter areas (Fig. 4b; Table 2, g). There was some additional evidence that godwits select nest sites with vegetation that exhibited less height variation (Fig. 4b; Table 2, k).

\section{Do willets and godwits differ in their habitat use?}

Marbled Godwits used nest sites with taller vegetation than willets, a finding corroborated by Robel field vegetation measurements (Fig. 4c; Table 2, i-j). Willet nest sites were flatter and closer to wetlands (Fig. 4c; Table 2, k-1). At the broader scale, which we associated with brood rearing habitat $(375 \mathrm{~m})$, godwits used flatter areas with greater wetland cover and less variation in vegetation height than Willets (Fig. 4c; Table 2, m-o).

Most willet and godwit nests occurred within $100 \mathrm{~m}$ of a wetland (willet mean $=65.1 \mathrm{~m}, \mathrm{sd}=65.7$; godwit: mean $=91.3 \mathrm{~m}, \mathrm{sd}=$ 89.7) and the distance from a nest to the nearest wetland edge did not vary by the cover type nests occurred in (grassland, hay land or cropland; Table 2, p). Willets nested by seasonal wetlands more often than expected and godwits nested by permanent wetlands more often than expected (Table 2, q). Although the majority of nests with a cover type identified in the nest record (742 nests) occurred within native grassland (658 nests, 438 willet, 220 godwit), $7 \%$ were found in cropland ( 28 willet, 25 godwit) and $4 \%$ in hayland (18 willet, 13 godwit), primarily reflecting where nesting searching was conducted. Relative to willets, godwit nests were found in cropland more often than expected (Table 2, r). 
Avian Conservation and Ecology 15(1): 3

http://www.ace-eco.org/vol15/iss1/art3/

Table 2. Estimates and statistics from data analyses, organized by question and in the order presented in the results section. Western Willet (Tringa semipalmata inornata) and Marbled Godwit (Limosa fedoa); BBS = North American Breeding Bird Survey.

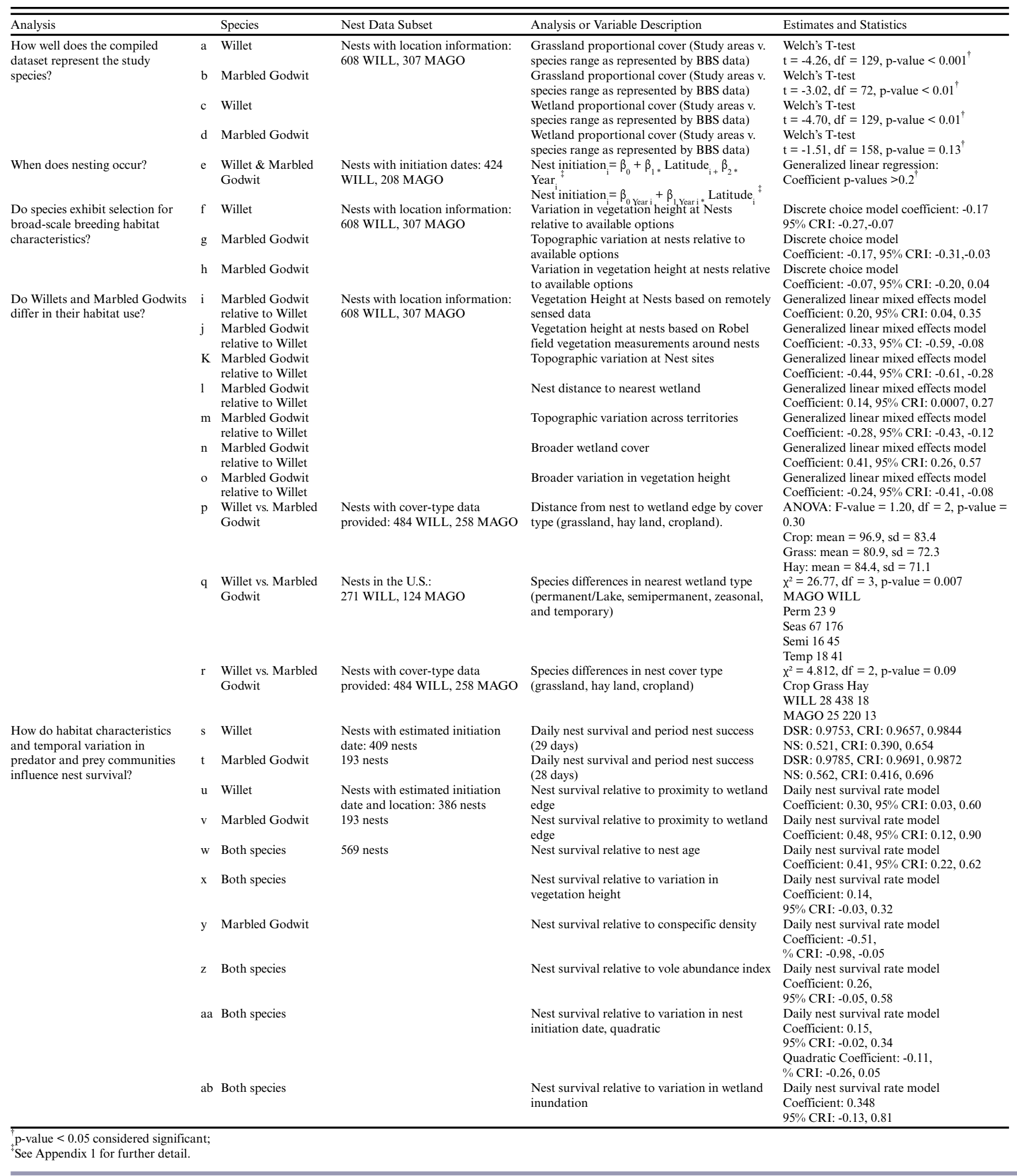


Fig. 4. Coefficient estimates from Bayesian discrete choice habitat selection models for selection of nest sites by Western Willets, Tringa semipalmata inornata ("W-") and Marbled Godwits, Limosa fedoa ("M-") and from Bayesian generalized linear models comparing characteristics of nest sites ("N-") and broader areas ("B-") between the species. Discrete choice habitat selection coefficients are relative to case-specific availability of nest sites for each species. Coefficients $>0$ in the comparisons of Marbled Godwit nest sites and broader areas to those of Willets suggest that this habitat characteristic had a higher value for Marbled Godwits than Willets (e.g. Marbled Godwits nested further from wetlands than Willets). Circles represent coefficient mean values, thick lines represent $80 \%$ credible interval, and thin lines represent the $95 \%$ credible interval.

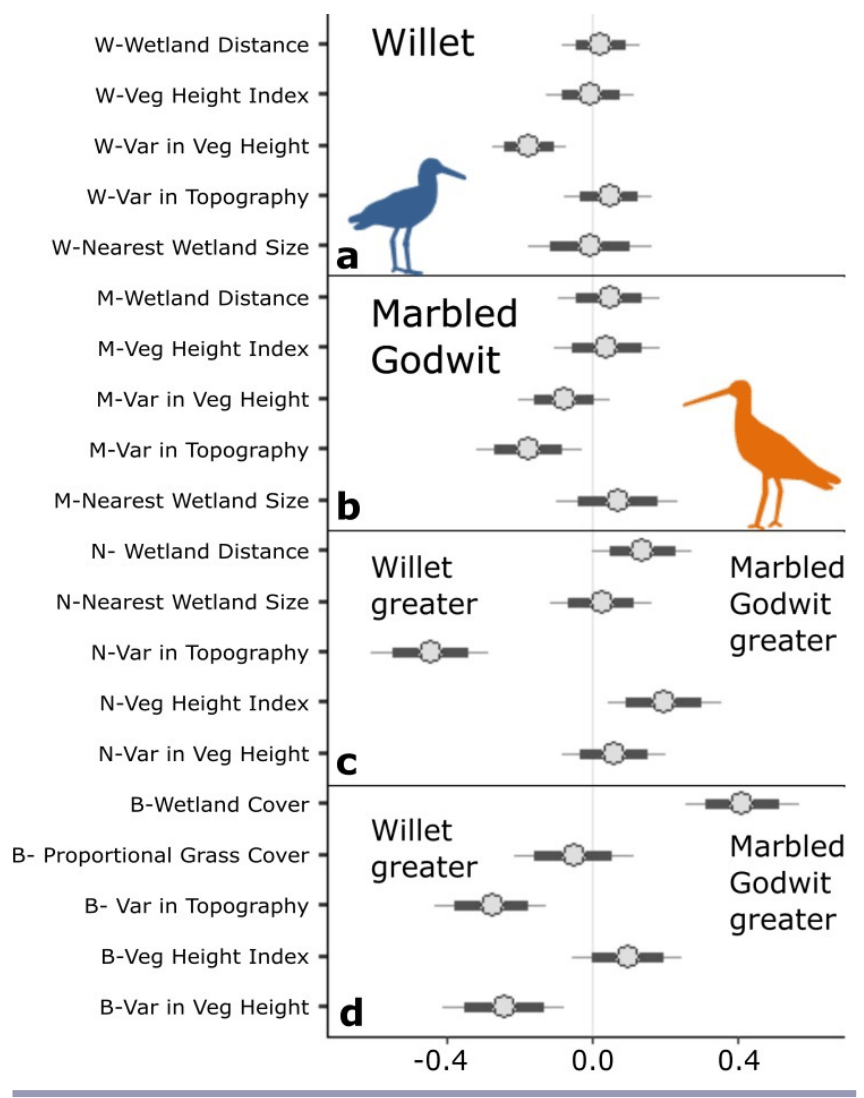

\section{How do habitat characteristics and temporal variation in predator and prey communities influence nest survival?}

Mean daily nest survival (DSR) was similar for willets $(0.9753$; Table 2, s) and godwits (0.9785; Table 2, t), after accounting for similarities in daily nest survival within years and study plots. At mean nest exposure periods of 29 days for willets and 28 days for godwits, this would result in period nest success rates of 0.521 (Table 2, s) for willets and 0.562 (Table 2, t) for godwits.

Daily nest survival increased with distance from the nearest wetland edge, nest age and variation in vegetation height at the nest and decreased with conspecific density for Marbled Godwits (Figs. 5 and 6; Table 2, u-y). There was also evidence of increasing nest survival with an index of Meadow voles (Microtus pennsylvanicus) abundance (voles being one of the primary prey sources for meso-carnivores that also eat eggs), nest initiation date and wetland inundation (Table 2, z-ab). After accounting for other habitat variables, there was no evidence that nest survival in cropland and hayland differed from grassland (Fig. 5). However, a post-hoc model estimating DSR for nests located in cropland and in hayland exhibited a broad posterior distribution for Willet daily nest survival $($ mean $=0.679$, sd $=0.333$ ) while providing fairly precise estimates for godwit nest survival in both cropland and hayland as well as precise estimates for both species in grassland. As such, this lack of evidence for differences in DSR by cover type could be influenced by large variability in willet nest survival. Substantial variation in nest survival was explained by random effects for both study area and year reflecting shifts in DSR of up to 0.03 which can result in changes in period nest survival of nearly $50 \%$ from the mean.

Fig. 5. Coefficient estimates from the Bayesian hierarchical daily nest survival model where circles represent coefficient mean values, thick lines represent $80 \%$ credible interval, and thin lines represent the $95 \%$ credible interval. Variables designated with "W" (Western Willet, Tringa semipalmata inornata) or "M" (Marbled Godwit, Limosa fedoa) represent those where relationships were allowed to vary between species in the model.

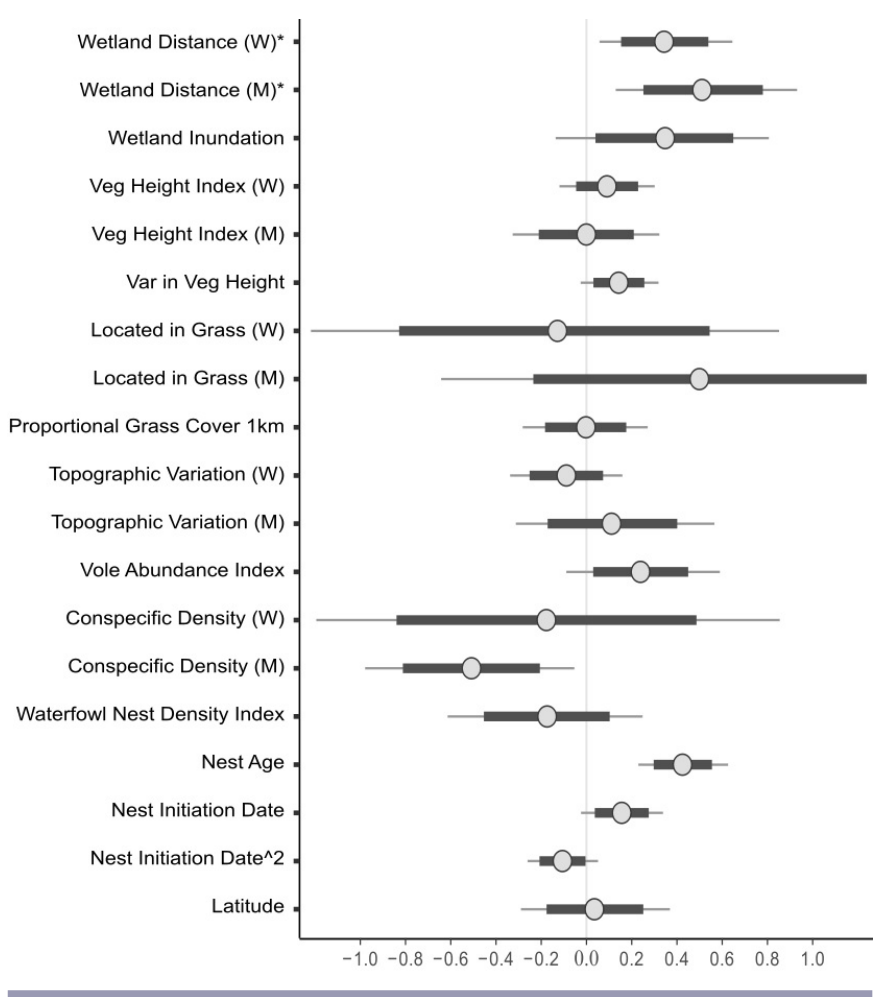

\section{How does data quality affect nest survival estimates?}

We found that including nest records for which nest age was not known resulted in estimates that differed substantially (greater than 
Fig. 6. Predicted period nest success or daily nest survival of Western Willet, Tringa semipalmata inornata (dashed blue line) and Marbled Godwit, Limosa fedoa (solid orange line) nests over the range of represented values for the distance of the nest to the nearest wetland edge, conspecific breeding density, and nest age. Envelopes represent model posterior density (with envelopes at 40,60, 80, and $90 \%$ of posterior density for each species).
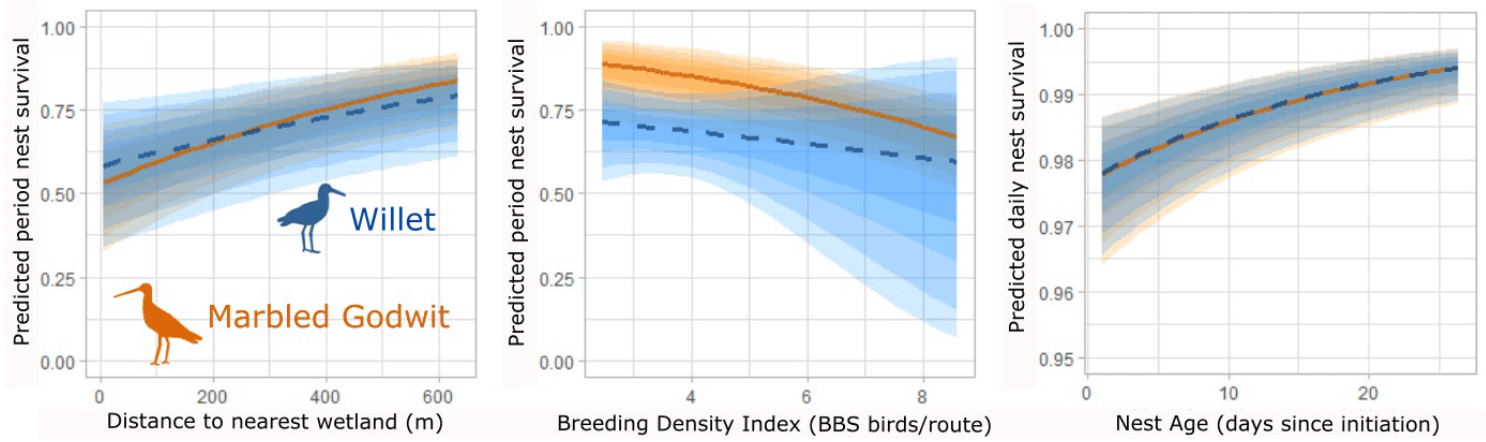

one standard deviation) from our reference data (for which nest ages were known; Appendix Table 2). We did not have a means of determining whether these differences resulted from observational bias (poor fate assessment) or from additional spatiotemporal variation that was represented by the addition of lower quality data to the dataset. However, lower quality data did little to contribute to estimation of ecological relationships to nest survival (Table A1.2).

\section{DISCUSSION}

We developed models of breeding habitat selection and daily nest survival for midcontinent populations of Western Willets and Marbled Godwits using nest data compiled from 20 studies (19702017) and ecological variables derived from remotely sensed data and broad-scale survey data. Our habitat selection models indicated differences between these two species in selection for certain habitat characteristics of nest sites and territories and provide a link between small-scale field studies and broad-scale models of occurrence throughout the breeding range. Distance to wetland had a stronger impact on nest survival for both species than did other habitat characteristics. Godwit nest survival was particularly sensitive to conspecific density while both species exhibited higher nest survival at later nest stages and initiation dates.

In this study, patterns identified using remotely sensed habitat variables corroborate findings from field measurements and observations, some of which emerged from component studies of our compiled dataset. For example, we found that godwits selected nesting sites that had taller vegetation than willets. After accounting for differences in measurement methods between study sites, field-based vegetation measurements from a subset of studies included in this dataset also indicated taller vegetation at willet nests. Additionally, willets have been observed to nest in grazed pastures more than godwits (Ryan and Renken 1987, Colwell and Oring 1988, Garvey et al. 2013; Ronningen, Skaggs, and Specht, personal observations), though both species avoid shrub and dense nesting cover (Higgins et al. 1979, Ryan 1984). In our study, godwits were more likely than willets to nest in cropland; this aligns with the component study finding that Willets nested preferentially in natural grazed and idled grassland cover while godwits nested in cover types proportional to their availability (Garvey et al. 2013).

Findings from our study also illuminate nuanced differences in habitat selection and use relative to habitat characteristics of the Northern Great Plains grasslands that are less variable over the course of the study period. Godwits selected flatter nest sites near larger, more permanent wetlands, and for territories with greater wetland cover than willets. This can be understood in the context of the gentle slopes that often surround broad, shallow permanent wetlands, in contrast to the rolling upland where less permanent wetlands occur and by which willets locate nests. Willets used nest sites closer to wetlands than godwits, though no different from other available habitat, indicating selection by willets for portions of the landscape with a greater density of smaller wetlands relative to godwits. This contrasts with Eastern Willets (T.S. semipalmata), which select salt over fresh water bodies (Lowther et al. 2001).

The coarser resolution of remotely sensed data (typically $30-\mathrm{m}$ resolution) relative to fine scale measurements typical of field studies (e.g., vegetation structure measurements around the nest cup as in Kantrud and Higgins 1992, Smith et al. 2007) was appropriate for the spatial precision of our nest location data. More importantly, it allowed us to utilize nest data compiled from many different field studies. For example, vegetation texture provides a within-habitat measure of vegetation complexity that has been used to predict avian species richness (St-Louis et al. 2006) and habitat use (Bellis et al. 2008) within habitat types. We used indices of vegetation height and texture derived from remotely sensed data in place of standard field measurements. We interpret willet selection for nest sites in grassland with little variation in vegetation height at nest locations as indicating selection for areas without shrub cover. Advances in geospatial environmental tools, such as Google Earth Engine, will soon provide the basis for evaluating habitat selection at a variety of scales for older datasets (e.g., Donnelly et al. 2019), while also creating opportunities to test habitat selection theory.

Our dataset also provided a sufficient sample to examine whether these grassland shorebirds select habitat that confers a fitness advantage at the scales and for the habitat characteristics 
evaluated (Orians 1980) because creating and maintaining quality habitat is the essence of wildlife management. Distance from the nest to the nearest wetland was the habitat characteristic with the greatest effect on nest survival, lending support for the hypothesis that selection for nest sites further from wetlands could reduce the risk of nest predation by edge-following predators (Phillips et al. 2003, Horn et al. 2005, Thompson et al. 2012). This effect was slightly stronger for godwits, which nested further from wetlands than willets and extended similar findings by Garvey et al. (2013, 70 nests included in this analysis) to a larger area. However, neither species selected nest sites closer to or further from wetlands relative to available options within their respective territories, indicating that substantial variation in proximity of nests to wetland edges across the region reflected the regional variation in wetland density within the habitats being searched. Similarly, willets exhibited selection for grassland nest sites with more homogenous vegetation height, but nest sites with greater heterogeneity in vegetation height exhibited higher nesting success, perhaps reflecting an advantage of increased crypsis. Although we have not identified specific, manageable habitat characteristics that are both selected for and confer a measurable fitness advantage amongst the variables and scales we've examined, this outcome is not entirely unexpected because habitat selection across different scales and social cues requires information with greater detail to discern (Orian and Wittenberger 1991, Ahlring and Faaborg 2006).

Most data in this study were collected as part of waterfowl studies that also examined habitat selection and nest survival, allowing not only comparisons to the breeding ecology of better studied shorebird species, but also to the findings of waterfowl studies that contributed data to this research. Both our study species and upland-nesting waterfowl exhibit higher daily nest survival rates later in the incubation period, independent of when nests are initiated (Klett and Johnson 1982, Stephens et al. 2005). This pattern may be driven by habitat selection, whereby daily nest survival improves with age because nests placed in vulnerable locations are quickly located and consumed by nest predators, as observed in waterfowl (Klett and Johnson 1982). Alternatively, nest survival might increase for older nests because incubating adults less willingly flush from or more actively defend eggs at later stages of incubation because of their greater reproductive value, a pattern observed in arctic-nesting shorebirds (Smith and Wilson 2010).

Improvement in reproductive outcomes during years and places with rodent irruptions is a pattern shared amongst upland-nesting shorebirds and waterfowl in temperate grassland and arctic tundra (e.g., Ackerman 2002, Smith et al. 2007, Specht and Arnold 2018). The benefit of rodent abundance is attributed to satiation and specialization of generalist nest predators on abundant rodents, to the benefit of other potential food sources, e.g., eggs or broods. Despite evidence of a relationship between upland-nesting waterfowl and shorebirds via shared nest predators and alternate prey, shorebird nest survival was not directly affected by waterfowl density. However, we did observe a negative effect of godwit density (as measured by BBS) on godwit nest survival. More detailed research is required to understand the mechanism of such an effect, which may be facilitated by predator and alternate prey densities (e.g., Lamarre et al. 2017) or by availability of high quality nesting habitat (Devries et al. 2018).
Daily nest survival rates of willets and godwits were similar to or higher than dabbling duck species when compared within the same sites and years (Kruse and Bowen 1996, Emery et al. 2005, Koper and Schmiegelow 2007, Howerter et al. 2014, Skaggs 2019). Higher daily nest survival for shorebirds relative to waterfowl is largely achieved by cryptic egg coloration (Skrade and Dinsmore 2013) and biparental incubation by willets and godwits, meaning that the nest can be actively defended virtually $100 \%$ of the time if a predator approaches (Smith and Wilson 2010). Estimated period nest success rates for willets $(0.521)$ and godwits $(0.562)$ were similar to Mayfield estimates for other upland-nesting prairie shorebirds such as Upland Sandpipers (Bartramia longicauda, 0.55; Bowen and Kruse 1993) and Long-billed Curlews (Numenius americanus, 0.33-0.69; Cochran and Anderson 1987, Pampush and Anthony 1993), but were likely much higher than apparent nest success of Eastern Willets $(0.19$ hatching success over 3 years in Virginia, no Mayfield estimate available; Howe 1982).

We carefully considered how the evolution of field methodology used to determine the incubation stage of a nest and whether eggs hatched or were depredated could influence nest survival analyses. Ultimately, we remained concerned that nest fate may have been inaccurately assessed for cases in which it was evaluated after a long monitoring interval or where expected hatch date was not determined. Indeed, evidence of depredation was variable at known depredated willet and godwit nests, suggesting that estimating hatch date is the most reliable means of correctly determining the fate ( 59 willet and 31 godwit nests; Gratto-Trevor 2000, Lowther et al. 2001). Ultimately, we excluded data from unaged nests in our nest survival models. Additionally, nests could only be encountered in landscapes that were searched, restricting inference related to habitat selection to native grassland, despite use of other cover types by both species. Unbiased samples of nest sites can be achieved by tracking birds with transmitters (Howerter et al. 2014, Sandercock et al. 2015). We emphasize the importance of understanding of how nest fate and location data were collected, including potential biases associated with censoring decisions and determination of nest fate, before using old nest records for nest survival analysis.

Considerations of data quality notwithstanding, compiling nest records from across studies allowed us to obtain range-wide estimates of daily nest survival and period nest success from over 500 nests. However, nest survival is only one component of reproductive success for species that raise precocial young; this dataset does not provide insight into renesting rate when nests fail or into survival of precocial young to fledge. At chick survival rates observed in other shorebird species $(0.45$ for Long-billed Curlews, Hartman and Oring 2009; 0.43 for Western Sandpipers, Calidris mauri, Ruthrauff and McCaffery 2005), willets and godwits could be expected to fledge $0.8-0.9$ chicks/female/year. However, this rate is much higher than what has been observed in southern Alberta, the only place where it has been tracked for one of these species ( 0.25 young/adult female Marbled Godwit/ year from 1996 to 1998; Gratto-Trevor 2000). We concur with Garvey et al. (2013) that further insight into population dynamics (and specifically declines) in midcontinent populations of willets and godwits will require additional evaluations of adult and juvenile survival. 
Our 50-year dataset allowed us to determine that, in grasslands of the Northern Great Plains, Western Willets nest in shorter vegetation, closer to less permanent wetlands and in more rugged areas than Marbled Godwits, which select nest sites in flatter areas near more permanent water bodies and in taller vegetation. Nest proximity to the nearest wetland exhibited the strongest habitat effect on nest survival, while nest age had a positive effect of comparable strength. We were able to discern patterns of selection and differences between species, even with the spatial imprecision resulting from hand-recorded maps, by accounting for studyspecific biases. Collaborative compilation and analysis of existing data, within the carefully considered constraints presented by the data collection approaches, is an increasingly important tool for understanding of the breeding ecology of data-sparse species.

Responses to this article can be read online at: http://www.ace-eco.org/issues/responses.php/1487

\section{Acknowledgments:}

H. Specht conceived of this analysis, organized the collaboration, procured archived data, conducted analyses, and wrote the manuscript. E. Kusik compiled nest records from different sources into a single database. $V$. St-Louis helped with habitat selection analyses and T. Arnold helped develop the nest survival model. All other authors contributed data and provided feedback on proposals and the manuscript. We are grateful to those that collected, archived and shared data for this study: K. Smith, T. Schaffer, T. Buhl, L. Igl, J. Austin, M. Garvey, K. Guyn, D. Howerter, J. Walker, R. Meidenger, B. Toay, H. Duebbert, K. Higgins, H. Kantrud, A. Kruse, and J. Lokemoen. Data collection was supported by private land owners; Environment and Climate Change Canada; Ducks Unlimited and Ducks Unlimited Canada; the Eastern Irrigation District AB; Delta Waterfowl; U.S. Fish and Wildlife Service; U. S.G.S Northern Prairie Wildlife Research Center; Prairie Farm Rehabilitation Association; The North American Waterfowl Management Plan; Alberta Sport, Recreation, Parks and Wildlife Foundation; Antelope Creek Habitat Development Area; Natural Sciences and Engineering Research Council; John and Patricia Schlosser Environment Scholarship; Izaak Walton Killam Memorial Scholarship; Bill Shostak Wildlife Award; Margaret Brown Award in Environmental Studies and Wildlife Resources; Ralph Steinhauer Award; the University of Alberta; North Dakota Game and Fish Department; McIntire-Stennis USDA-NIFA (\#94294); Louisiana State University AgCenter; Dave Ankney \& Sandi Johnson Waterfowl and Wetlands Graduate Research Scholarship; John Barton Sr. Graduate Wildlife Scholarship; California Fish and Game; Conservation International; Alberta Bucks for Wildlife Program; University of Saskatchewan; National Science Foundation Grant (\#00039202) and the University of Minnesota Graduate School. This manuscript benefited from feedback by G. McCaffrey, H. Reich, N. Niemuth, and F. Cuthbert.

\section{LITERATURE CITED}

Ackerman, J. T. 2002. Of mice and mallards: positive indirect effects of coexisting prey on waterfowl nest success. Oikos 99:469_ 480. https://doi.org/10.1034/j.1600-0706.2002.11802.x
Ahlring, M. A., and J. Faaborg. 2006. Avian habitat management meets conspecific attraction: If you build it, will they come? $A u k$ 123:301-312. https://doi.org/10.1642/0004-8038(2006)123[301: AHMMCA]2.0.CO;2

Baasch, D. M., A. J. Tyre, J. J. Millspaugh, S. E. Hygnstrom, and K. C. Vercauteren. 2010. An evaluation of three statistical methods used to model resource selection. Ecological Modelling 221:565-574. https://doi.org/10.1016/j.ecolmodel.2009.10.033

Bellis, L. M., A. M. Pidgeon, V. C. Radeloff, V. St-Louis, J. L. Navarro, and M. B. Martella. 2008. Modeling habitat suitability for Greater Rheas based on satellite image texture. Ecological Applications 18:1956-1966. https://doi.org/10.1890/07-0243.1

Bowen, B. S., and A. D. Kruse. 1993. Effects of grazing on nesting by Upland Sandpipers in southcentral North-Dakota. Journal of Wildlife Management 57:291-301. https://doi.org/10.2307/3809426

Brockway, D. G., R. G. Gatewood, and R. B. Paris. 2002. Restoring fire as an ecological process in shortgrass prairie ecosystems: initial effects of prescribed burning during the dormant and growing seasons. Journal of Environmental Management 65:135-152. https://doi.org/10.1006/jema.2002.0540

Brook, R. W., M. Pasitschniak-Arts, D. W. Howerter, and F. Messier. 2008. Influence of rodent abundance on nesting success of prairie waterfowl. Canadian Journal of Zoology 86:497-506. https://doi.org/10.1139/Z08-019

Chalfoun, A. D., and T. E. Martin. 2007. Assessments of habitat preferences and quality depend on spatial scale and metrics of fitness. Journal of Applied Ecology 44:983-992. https://doi. org/10.1111/j.1365-2664.2007.01352.x

Clark, R. G., and D. Shutler. 1999. Avian habitat selection: pattern from process in nest-site use by ducks? Ecology 80:272-287. https://doi.org/10.1890/0012-9658(1999)080[0272:AHSPFP]2.0.CO;2

Cochran, J. F., and S. H. Anderson. 1987. Comparison of habitat attributes at sites of stable and declining Long-billed Curlew populations. Great Basin Naturalist 47:459-466.

Colwell, M. A., and L. W. Oring. 1988. Breeding biology of Wilson's Phalarope in southcentral Saskatchewan. Wilson Bulletin 100:567-582.

Cooper, A. B., and J. J. Millspaugh. 1999. The application of discrete choice models to wildlife resource selection studies. Ecology 80:566-575. https://doi.org/10.1890/0012-9658(1999)080 [0566:TAODCM]2.0.CO;2

Cowardin, L. M., V. Carter, F. C. Golet, and E. T. LaRoe. 1979. Classification of wetlands and deepwater habitats of the United States. FWS/OBS-79/31. U.S. Fish and Wildlife Service, Washington, D.C., USA. https://doi.org/10.1002/047147844X. sw2162

de Szalay, F. A. De, L. C. Carroll, J. A. Beam, and V. H. Resh. 2003. Temporal overlap of nesting duck and aquatic invertebrate abundances in the Grasslands Ecological Area, California, USA. Wetlands 23:739-749. https://doi.org/10.1672/0277-5212(2003) 023[0739:TOONDA]2.0.CO;2

Devries, J. H., R. G. Clark, and L. M. Armstrong. 2018. Dynamics of habitat selection in birds: adaptive response to nest predation 
depends on multiple factors. Oecologia 187:305-318. https://doi. org/10.1007/s00442-018-4134-2

Donnelly, J. P., D. E. Naugle, D. P. Collins, B. D. Dugger, B. W. Allred, J. D. Tack, and V. J. Dreitz. 2019. Synchronizing conservation to seasonal wetland hydrology and waterbird migration in semi-arid landscapes. Ecosphere 10:e2758. https:// doi.org/10.1002/ecs2.2758

Emery, R. B., D. W. Howerter, L. M. Armstrong, M. G. Anderson, J. H. Devries, and B. L. Joynt. 2005. Seasonal variation in waterfowl nesting success and its relation to cover management in the Canadian prairies. Journal of Wildlife Management 69:1181-1193. https://doi.org/10.2193/0022-541X(2005)069[1181: SVIWNS]2.0.CO;2

Galbraith, H. 1988. Effects of agriculture on the breeding ecology of Lapwings Vanellus vanellus. Journal of Applied Ecology 25:487-503. https://doi.org/10.2307/2403839

Garvey, M. E., E. Nol, D. W. Howerter, and L. M. Armstrong. 2013. A spatial analysis of factors affecting nesting success of shorebirds in the Canadian prairies. Condor 115:58-66. https:// doi.org/10.1525/cond.2012.110146

Gelman, A., and D. B. Rubin. 1992. Inference from iterative simulation using multiple sequences. Statistical Science 7:457-472. https://doi.org/10.1214/ss/1177011136

Giudice, J. H., J. R. Fieberg, and M. S. Lenarz. 2012. Spending degrees of freedom in a poor economy: a case study of building a sightability model for moose in northeastern Minnesota. Journal of Wildlife Management 76:75-87. https://doi.org/10.1002/ jwmg.213

Gratto-Trevor, C. L. 2000. Marbled Godwit (Limosa fedoa), version 2.0. In A. F. Poole and F. B. Gill, editors. The birds of North America. Cornell Lab of Ornithology, Ithaca, New York, USA. https://doi.org/10.2173/bna.492

Gratto-Trevor, C. L. 2006. Upland-nesting prairie shorebirds: use of managed wetland basins and accuracy of breeding surveys. Avian Conservation and Ecology 1(2):2. https://doi.org/10.5751/ ACE-00042-010202

Greenwood, R. J., A. B. Sargeant, D. H. Johnson, L. M. Cowardin, and T. L. Shaffer. 1995. Factors associated with duck nest success in the Prairie Pothole Region of Canada. Wildlife Monographs 128:1-57.

Harrell, F. 2015. Regression modeling strategies: with applications to linear models, logistic and ordinal regression, and survival analysis. Springer, New York, New York, USA.

Hartman, C. A., and L. W. Oring. 2009. Reproductive success of Long-billed Curlews (Numenius americanus) in northeastern Nevada hay fields. Auk 126:420-430. https://doi.org/10.1525/ auk.2009.08062

Higgins, K. F., L. M. Kirsch, M. R. Ryan, and R. B. Renken. 1979. Some ecological aspects of Marbled Godwits and Willets in North Dakota. Prairie Naturalist 11:115-118.

Horn, D. J., M. L. Phillips, R. R. Koford, W. R. Clark, M. A. Sovada, and R. J. Greenwood. 2005. Landscape composition, patch size, and distance to edges: interactions affecting duck reproductive success. Ecological Applications 15:1367-1376. https://doi.org/10.1890/03-5254

Howe, M. A. 1982. Social organization in a nesting population of Eastern Willets (Catoptrophorus semipalmatus). Auk 99:88-102. https://doi.org/10.2307/4086024

Howerter, D. W., M. G. Anderson, J. H. Devries, B. L. Joynt, L. M. Armstrong, R. B. Emery, and T. W. Arnold. 2014. Variation in Mallard vital rates in Canadian Aspen Parklands: the Prairie Habitat Joint Venture assessment. Wildlife Monographs 188:1-37. https://doi.org/10.1002/wmon.1012

Johnson, D. H., A. B. Sargeant, and R. J. Greenwood. 1989. Importance of individual species of predators on nesting success of ducks in the Canadian Prairie Pothole Region. Canadian Journal of Zoology 67:291-297. https://doi.org/10.1139/z89-043

Johnston, C. A. 2013. Wetland losses due to row crop expansion in the Dakota Prairie Pothole Region. Wetlands 33:175-182. https://doi.org/10.1007/s13157-012-0365-X

Kantrud, H. A., and K. F. Higgins. 1992. Nest and nest site characteristics of same ground-nesting, non-passerine birds of Northern Grasslands. Prairie Naturalist 24:67-84.

Kellner, K. 2019. jagsUI: A wrapper around 'rjags' to streamline 'JAGS' analyses. R package version 1.5.1. [online] URL: http:// CRAN.R-project.org/package=jagsUI

Kéry, M., and M. Schaub. 2012. Bayesian population analysis using WinBUGS: a hierarchical perspective. Elsevier, Waltham, Massachusetts, USA. https://doi.org/10.1016/C2010-0-68368-4

Klett, A. T., H. F. Duebbert, C. A. Faanes, and K. F. Higgins. 1986. Techniques for studying nest success of ducks in upland habitats in the prairie pothole region. Resource Publication 158. U.S. Fish and Wildlife Service, Washington, D.C., USA.

Klett, A. T., and D. H. Johnson. 1982. Variability in nest survival rates and implications to nesting studies. Auk 99:77-87. https:// doi.org/10.2307/4086023

Koper, N., and F. K. A. Schmiegelow. 2007. Does management for duck productivity affect songbird nesting success? Journal of Wildlife Management 71:2249-2257. https://doi.org/10.2193/2006-354

Kruse, A. D. and B. S. Bowen. 1996. Effects of grazing and burning on densities and habitats of breeding ducks in North Dakota. Journal of Wildlife Management 60:233-246 https://doi. org/10.2307/3802221

Kwon, E., W. B. English, E. L. Weiser, S. E. Franks, D. J. Hodkinson, D. B. Lank, and B. K. Sandercock. 2018. Delayed egg-laying and shortened incubation duration of Arctic-breeding shorebirds coincide with climate cooling. Ecology and Evolution 8:1339-1351. https://doi.org/10.1002/ece3.3733

La Pierre, K. J., D. M. Blumenthal, C. S. Brown, J. A. Klein, and M. D. Smith. 2016. Drivers of variation in aboveground net primary productivity and plant community composition differ across a broad precipitation gradient. Ecosystems 19:521-533. https://doi.org/10.1007/s10021-015-9949-7

Lamarre, J.-F., P. Legagneux, G. Gauthier, E. T. Reed, and J. Bêty. 2017. Predator-mediated negative effects of overabundant Snow 
Geese on arctic-nesting shorebirds. Ecosphere 8:e01788. https:// doi.org/10.1002/ecs2.1788

Leitch, W. G., and R. M. Kaminski. 1985. Long-term wetlandwaterfowl trends in Saskatchewan grasslands. Journal of Wildlife Management 49:212-222. https://doi.org/10.2307/3801873

Liebezeit, J. R., S. J. Kendall, S. Brown, C. B. Johnson, P. Martin, T. L. McDonald, D. C. Payer, C. L. Rea, B. Streever, A. M. Wildman, and S. Zack. 2009. Influence of human development and predators on nest survival of tundra birds, Arctic Coastal Plain, Alaska. Ecological Applications 19:1628-1644. https://doi. org/10.1890/08-1661.1

Liebezeit, J. R., P. A. Smith, R. B. Lanctot, H. Schekkerman, I. Tulp, S. J. Kendall, D. M. Tracy, R. J. Rodrigues, H. Meltofte, J. A. Robinson, C. Gratto-Trevor, B. J. McCaffery, J. Morse, and S. W. Zack. 2007. Assessing the development of shorebird eggs using the flotation method: species-specific and generalized regression models. Condor 109:32-47. https://doi.org/10.1093/condor/109.1.32

Lowther, P. E., H. D. Douglas III, and C. L. Gratto-Trevor. 2001. Willet (Tringa semipalmata), version 2.0. In A. F. Poole and F. B. Gill, editors. The birds of North America. Cornell Lab of Ornithology, Ithaca, New York, USA. https://doi.org/10.2173/ bna. 579

Ludlow, S. M., and S. K. Davis. 2018. Oil and natural gas development influence nest-site selection and nest survival of upland-nesting waterfowl and shorebirds. Wildlife Society Bulletin 42:57-66. https://doi.org/10.1002/wsb.849

Mabee, T. J. 1997. Using eggshell evidence to determine nest fate of shorebirds. Wilson Bulletin 109:307-313.

Mabee, T. J., A. M. Wildman, and C. B. Johnson. 2006. Using egg flotation and eggshell evidence to determine age and fate of Arctic shorebird nests. Journal of Field Ornithology 77:163-172. https:// doi.org/10.1111/j.1557-9263.2006.00037.x

Marsett, R. C., J. Qi, P. Heilman, S. H. Biedenbender, M. C. Watson, S. Amer, M. Weltz, D. Goodrich, and R. Marsett. 2006. Remote sensing for grassland management in the arid Southwest. Rangeland Ecology and Management 59:530-540. https://doi. org/10.2111/05-201R.1

Martin, T. E. 1993. Nest predation and nest sites: new perspectives on old patterns. BioScience 43:523-532. https://doi.org/10.2307/1311947

McCarty, J. P. 2001. Ecological consequences of recent climate change. Conservation Biology 15:320-331. https://doi.org/10.1046/ j.1523-1739.2001.015002320.x

McFadden, D. 1978. Modeling the choice of residential location. Pages 79-96 in A. Karlquist, editor. Spatial interaction theory and planning models. North Holland, Amsterdam, The Netherlands.

McKinnon, L., D. Berteaux, and J. Bêty. 2014. Predator-mediated interactions between lemmings and shorebirds: a test of the alternative prey hypothesis. Auk 131:619-628. https://doi. org/10.1642/AUK-13-154.1

McKinnon, L., P. A. Smith, E. Nol, J. L. Martin, F. I. Doyle, K. F. Abraham, H. G. Gilchrist, R. I. G. Morrison, and J. Bêty. 2010. Lower predation risk for migratory birds at high latitudes. Science 327:326-327. https://doi.org/10.1126/science.1183010
McMaster, D. G., J. H. Devries, and S. K. Davis. 2005. Grassland birds nesting in haylands of southern Saskatchewan: landscape influences and conservation priorities. Journal of Wildlife Management 69:211-221. https://doi.org/10.2193/0022-541X (2005)069<0211:GBNIHO>2.0.CO;2

Niemuth, N. D., and J. W. Solberg. 2003. Response of waterbirds to number of wetlands in the Prairie Pothole Region of North Dakota, USA. Waterbirds 26:233-238. https://doi.org/10.1675/1524-4695 (2003)026[0233:ROWTNO]2.0.CO;2

Orians, G. H. 1980. Habitat selection: general theory and applications to human behavior. Pages 49-66 in J. S. Lockard, editor. Evolution of human social behavior. Elsevier, New York, New York, USA.

Orians, G. H., and J. F. Wittenberger. 1991. Spatial and temporal scales in habitat selection. American Naturalist 137:S29-S49. https://doi.org/10.1086/285138

Pampush, G. J., and R. G. Anthony. 1993. Nest success, habitat utilization and nest-site selection of Long-Billed Curlews in the Columbia Basin, Oregon. Condor 95:957-967. https://doi. org/10.2307/1369431

Pardieck, K. L., D. J. Ziolkowski Jr., M. Lutmerding, V. Aponte, and M. A. R. Hudson. 2019. North American Breeding Bird Survey dataset 1966-2016, version 2018.0. U.S. Geological Survey, Patuxent Wildlife Research Center, Laurel, Maryland, USA. [online] URL: https://www.pwrc.usgs.gov/BBS/results/

Phillips, M. L., W. R. Clark, M. A. Sovada, D. J. Horn, R. R. Koford, and R. J. Greenwood. 2003. Predator selection of prairie landscape features and its relation to duck nest success. Journal of Wildlife Management 67:104-114. https://doi.org/10.2307/3803066

Plummer, M. 2003. JAGS: a program for analysis of Bayesian graphical models using Gibbs sampling. Proceedings of the $3 \mathrm{rd}$ International Workshop on Distributed Statistical Computing, Vol. 124. Technische Universität Wien, Vienna, Austria.

Poulin, R., T. Wellicome, and L. Todd. 2001. Synchronous and delayed numerical responses of a predatory bird community to a vole outbreak on the Canadian prairies. Journal of Raptor Research 35:288-295.

R Core Team. 2018. R: A language and environment for statistical computing. R Foundation for Statistical Computing, Vienna, Austria. [online] URL: https://www.R-project.org/

Reid, J. M., W. Cresswell, S. Holt, R. J. Mellanby, D. P. Whitfield, and G. D. Ruxton. 2002. Nest scrape design and clutch heat loss in Pectoral Sandpipers (Calidris melanotos). Functional Ecology 16:305-312. https://doi.org/10.1046/j.1365-2435.2002.00632.x

Reynolds, R. E., T. L. Shaffer, C. R. Loesch, and R. R. Cox Jr. 2006. The farm bill and duck production in the Prairie Pothole Region: increasing the benefits. Wildlife Society Bulletin 34:963-974. https://doi.org/10.2193/0091-7648(2006)34[963:TFBADP] 2.0. $\mathrm{CO} ; 2$

Ruthrauff, D. R., and B. J. McCaffery. 2005. Survival of Western Sandpiper broods on the Yukon-Kuskokwim Delta, Alaska. Condor 107:597-604. https://doi.org/10.1093/condor/107.3.597 
Ruxton, G. D. 2006. The unequal variance $t$-test is an underused alternative to Student's $t$-test and the Mann-Whitney $U$ test. Behavioral Ecology 4:688-690. https://doi.org/10.1093/beheco/ ark016

Ryan, M., and R. B. Renken. 1987. Habitat use by breeding Willets in the Northern Great Plains. Wilson Bulletin 99:175-189.

Ryan, M. R., R. B. Renken, and J. J. Dinsmore. 1984. Marbled Godwit habitat selection in the Northern Prairie Region. Journal of Wildlife Management 48:1206-1218. https://doi.org/10.2307/3801782

Sandercock, B. K., M. Alfaro-Barrios, A. E. Casey, T. N. Johnson, T. W. Mong, K. J. Odum, K. M. Strum, and V. L. Winder. 2015. Effects of grazing and prescribed fire on resource selection and nest survival of Upland Sandpipers in an experimental landscape. Landscape Ecology 30:325-337. https://doi.org/10.1007/s10980-014-0133-9

Sargeant, A. B., R. J. Greenwood, M. A. Sovada, and T. L. Shaffer. 1993. Distribution and abundance of predators that affect duck production-Prairie Pothole Region. Resource Publication 194. U. S. Department of the Interior Fish and Wildlife Service, Washington, D.C., USA. [online] URL: https://apps.dtic.mil/dtic/ tr/fulltext/u2/a322696.pdf

Saunders, S. P., M. T. Farr, A. D. Wright, C. A. Bahlai, J. W. Ribeiro Jr., S. Rossman, A. L. Sussman, T. W. Arnold, and E. F. Zipkin. 2019. Disentangling data discrepancies with integrated population models. Ecology 100:e02714. https://doi.org/10.1002/ ecy. 2714

Schmidt, K. A. 1999. Foraging theory as a conceptual framework for studying nest predation. Oikos 85:151-160. https://doi. org/10.2307/3546801

Shaffer, T. L. 2004. A unified approach to analyzing nest success. Auk 121:526-540. https://doi.org/10.1642/0004-8038(2004)121 [0526:AUATAN]2.0.CO;2

Skaggs, C. 2019. Effects of oil and gas development on waterfowl nesting ecology in the Bakken Formation of North Dakota. Thesis. Louisiana State University, Baton Rouge, Louisiana, USA.

Skrade, P. D. B., and S. J. Dinsmore. 2013. Egg crypsis in a groundnesting shorebird influences nest survival. Ecosphere 4:1-9. https://doi.org/10.1890/ES13-00246.1

Smith, A. C., M-A. R. Hudson, V. Aponte, and C. M. Francis. 2019. North American Breeding Bird Survey - Canadian trends website, data-version 2017. Environment and Climate Change Canada, Gatineau, Québec, Canada. [online] URL: https:// wildlife-species.canada.ca/breeding-bird-survey-results

Smith, J. T., J. D. Tack, K. E. Doherty, B. W. Allred, J. D. Maestas, L. I. Berkeley, S. J. Dettenmaier, T. A. Messmer, and D. E. Naugle. 2018. Phenology largely explains taller grass at successful nests in Greater Sage-Grouse. Ecology and Evolution 8:356-364. https:// doi.org/10.1002/ece3.3679

Smith, P. A., H. G. Gilchrist, and J. N. M. Smith. 2007. Effects of nest habitat, food, and parental behavior on shorebird nest success. Condor 109:15-31. https://doi.org/10.1093/condor/109.1.15

Smith, P. A., and S. Wilson. 2010. Intraseasonal patterns in shorebird nest survival are related to nest age and defense behavior. Oecologia 163:613-624. https://doi.org/10.1007/ s00442-010-1644-y

Specht, H. M. 2018. Habitat use and reproductive success of waterbirds in the human-dominated landscape of North America's prairies: using sparse data to inform management. Dissertation. Conservation Sciences, University of Minnesota, St. Paul, Minnesota, USA. [online] URL: https://conservancy.umn.edu/ handle/11299/199012

Specht, H. M., and T. W. Arnold. 2018. Banding age ratios reveal prairie waterfowl fecundity is affected by climate, density dependence and predator-prey dynamics. Journal of Applied Ecology 55:2854-2864. https://doi.org/10.1111/1365-2664.13186

St-Louis, V., A. M. Pigeon, V. C. Radeloff, T. J. Hawbaker, and M. K. Clayton. 2006. High-resolution image texture as a predictor of bird species richness. Remote Sensing of Environment 105:299-312. https://doi.org/10.1016/j.rse.2006.07.003

Stanley, T. R. 2004. When should Mayfield model data be discarded? Wilson Journal of Ornithology 116:267-269. https:// doi.org/10.1676/04-042

Stephens, S. E., J. J. Rotella, M. S. Lindberg, M. L. Taper, and J. K. Ringelman. 2005. Duck nest survival in the Missouri Coteau of North Dakota: landscape effects at multiple spatial scales. Ecological Applications 15:2137-2149. https://doi.org/10.1890/04-1162

Stephens, S. E., J. A. Walker, D. R. Blunck, A. Jayaraman, D. E. Naugle, J. K. Ringelman, and A. J. Smith. 2008. Predicting risk of habitat conversion in native temperate grasslands. Conservation Biology 22:1320-1330. https://doi.org/10.1111/ j.1523-1739.2008.01022.x

Thompson, S. J., T. W. Arnold, and S. Vacek. 2012. Impact of encroaching woody vegetation on nest success of upland-nesting waterfowl. Journal of Wildlife Management 76:1635-1642. https:// doi.org/10.1002/jwmg.415

Waisanen, P. J., and N. B. Bliss. 2002. Changes in population and agricultural land in conterminous United States counties, 1790 to 1997. Global Biogeochemical Cycles 16:84-1-84-19. https://doi. org/10.1029/2001gb001843

Weiser, E. L., S. C. Brown, R. B. Lanctot, H. R. Gates, K. F. Abraham, R. L. Bentzen, J. Bêty, M. L. Boldenow, R. W. Brook, T. F. Donnelly, W. B. English, S. A. Flemming, S. E. Franks, H. G. Gilchrist, M. A. Giroux, A. Johnson, S. Kendall, L. V. Kennedy, L. Koloski, E. Kwon, J.-F. Lamarre, D. B. Lank, C. J. Latty, N. Lecomte, J. R. Liebezeit, L. Mckinnon, E. Nol, J. Perz, J. Rausch, M. Robards, S. T. Saalfeld, N. R. Senner, P. A. Smith, M. Soloviev, D. Solovyeva, D. H. Ward, P. F. Woodard, and B. K. Sandercock. 2018. Effects of environmental conditions on reproductive effort and nest success of Arctic-breeding shorebirds. Ibis 160:608-623. https://doi.org/10.1111/ibi.12571

Winter, M., D. H. Johnson, and J. A. Shaffer. 2005. Variability in vegetation effects on density and nesting success of grassland birds. Journal of Wildlife Management 69:185-197. https://doi. org/10.2193/0022-541X(2005)069<0185:VIVEOD>2.0.CO;2

Zhao, Q., T. W. Arnold, J. H. Devries, D. W. Howerter, R. G. Clark and M. D. Weegman. 2019. Land-use change increases climatic 
Avian Conservation and Ecology 15(1): 3 http://www.ace-eco.org/vol15/iss1/art3/

vulnerability of migratory birds: insights from integrated population modelling. Journal of Animal Ecology 88:1625-1637. https://doi.org/10.1111/1365-2656.13043

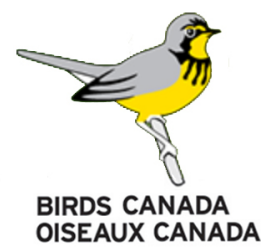




\section{Appendix 1}

Appendix materials to accompany: Specht, H.M., V. St-Louis, C. Gratto-Trevor, N. Koper, C. Skaggs, T. Ronningen and T.W. Arnold. 2019. Habitat selection and nest survival in two Great Plains shorebirds. Avian Conservation and Ecology.

\section{Tables}

Table A1.1. Sources of Marbled Godwit and Willet nest records compiled to assess habitat selection and nest survival in the Northern Great Plains.

\begin{tabular}{|c|c|c|c|c|c|c|}
\hline $\begin{array}{l}\text { Principle } \\
\text { Investigators }\end{array}$ & $\begin{array}{l}\text { Institutional } \\
\text { Affiliations }\end{array}$ & $\begin{array}{c}\text { Study } \\
\text { Location }\end{array}$ & $\begin{array}{l}\text { Study } \\
\text { Years }\end{array}$ & $\begin{array}{l}\text { MAGO } \\
\text { nests }\end{array}$ & $\begin{array}{l}\text { WILL } \\
\text { nests }\end{array}$ & Associated Publications \\
\hline Gratto-Trevor & $\begin{array}{l}\text { Environment } \\
\text { and Climate } \\
\text { Change Canada }\end{array}$ & $A B$ & $1995-2000$ & 132 & 206 & $\begin{array}{l}\text { Gratto-Trevor, C. L. 2006. Upland-nesting prairie } \\
\text { shorebirds: use of managed wetland basins and } \\
\text { accuracy of breeding surveys. Avian Conservation } \\
\text { and Ecology 1(2):2. } \\
\text { Gratto-Trevor, C.L., 2011. Connectivity in Willets and } \\
\text { Marbled Godwits breeding in western Canada. } \\
\text { Wader Study Gr. Bull. 118, 55-57. }\end{array}$ \\
\hline $\begin{array}{l}\text { Howerter, } \\
\text { Garvey, Guyn \& } \\
\text { Emery }\end{array}$ & $\begin{array}{l}\text { Ducks } \\
\text { Unlimited, } \\
\text { Canada- } \\
\text { Institute for } \\
\text { Waterfowl and } \\
\text { Wetlands } \\
\text { Research }\end{array}$ & $\begin{array}{c}A B, M B, \\
S K\end{array}$ & $\begin{array}{c}\text { 1994,2003, } \\
2005- \\
2009,2011\end{array}$ & 57 & 198 & $\begin{array}{l}\text { Emery, R. B., D. W. Howerter, L. M. Armstrong, M. G. } \\
\text { Anderson, J. H. Devries, and B. L. Joynt. } 2005 . \\
\text { Seasonal variation in waterfowl nesting success } \\
\text { and its relation to cover management in the } \\
\text { Canadian prairies. The Journal of Wildlife } \\
\text { Management 69:1181-1193. } \\
\text { Guyn, K. L., and R. G. Clark. 2000. Nesting effort of } \\
\text { Northern Pintails in Alberta. Condor 102:619-628. } \\
\text { Garvey, M. E., E. Nol, D. W. Howerter, and L. M. } \\
\text { Armstrong. 2013. A spatial analysis of factors } \\
\text { affecting nesting success of shorebirds in the } \\
\text { Canadian prairies. The Condor 115:58-66. }\end{array}$ \\
\hline $\begin{array}{l}\text { Duebbert,Higgins, } \\
\text { Kantrud, Klett, } \\
\text { Kruse, Lokemoen }\end{array}$ & $\begin{array}{l}\text { USGS Northern } \\
\text { Prairie Wildlife } \\
\text { Research } \\
\text { Center }\end{array}$ & ND, SD & 1970-1989 & 78 & 117 & $\begin{array}{l}\text { Higgins, K. F. 1977. Duck nesting in intensively farmed } \\
\text { areas of North Dakota. Journal of Wildlife } \\
\text { Management 41:232-242. } \\
\text { Higgins, K. F., L. M. Kirsch, M. R. Ryan, and R. B. Renken. } \\
\text { 1979. Some ecological aspects of Marbled } \\
\text { Godwits and Willets in North Dakota. Prairie } \\
\text { Naturalist 11:115-118. } \\
\text { Duebbert, H. F., and H. A. Kantrud. 1987. Use of no-till } \\
\text { winter wheat by nesting ducks in North Dakota. } \\
\text { Journal of Soil and Water Conservation 42:50-53. }\end{array}$ \\
\hline
\end{tabular}




\section{Table A1.1 continued}

\begin{tabular}{|c|c|c|c|c|c|c|}
\hline $\begin{array}{l}\text { Principle } \\
\text { Investigators }\end{array}$ & $\begin{array}{l}\text { Institutional } \\
\text { Affiliations }\end{array}$ & $\begin{array}{c}\text { Study } \\
\text { Location }\end{array}$ & $\begin{array}{l}\text { Study } \\
\text { Years }\end{array}$ & $\begin{array}{c}\text { MAGO } \\
\text { nests }\end{array}$ & $\begin{array}{l}\text { WILL } \\
\text { nests }\end{array}$ & Associated Publications \\
\hline $\begin{array}{l}\text { Duebbert, Higgins, } \\
\text { Kantrud, Klett, } \\
\text { Kruse, Lokemoen } \\
\text { continued }\end{array}$ & $\begin{array}{l}\text { USGS Northern } \\
\text { Prairie Wildlife } \\
\text { Research } \\
\text { Center }\end{array}$ & $\mathrm{ND}, \mathrm{SD}$ & 1970-1989 & 78 & 117 & $\begin{array}{l}\text { Kantrud, H. A., and K. F. Higgins. 1992. Nest and nest } \\
\text { site characteristics of same ground-nesting, non- } \\
\text { passerine birds of Northern Grasslands. Prairie } \\
\text { Naturalist 24:67-84. } \\
\text { Kruse, A. D., and B. S. Bowen. 1996. Effects of grazing } \\
\text { and burning on densities and habitats of breeding } \\
\text { ducks in North Dakota. Journal of Wildlife } \\
\text { Management 60:233-246. }\end{array}$ \\
\hline $\begin{array}{l}\text { Walker, } \\
\text { Stephens, } \\
\text { Meidinger \& Toay }\end{array}$ & $\begin{array}{c}\text { Ducks } \\
\text { Unlimited, Inc. }\end{array}$ & ND & $\begin{array}{c}\text { 2001, } \\
\text { 2003-2009 }\end{array}$ & 37 & 112 & $\begin{array}{l}\text { Stephens, S. E., J. J. Rotella, M. S. Lindberg, M. L. Taper, } \\
\text { and J. K. Ringelman. 2005. Duck nest survival in } \\
\text { the Missouri Coteau of North Dakota: Landscape } \\
\text { effects at multiple spatial scales. Ecological } \\
\text { Applications 15:2137-2149. }\end{array}$ \\
\hline Koper & $\begin{array}{c}\text { University of } \\
\text { Manitoba }\end{array}$ & $A B$ & 2000-2002 & 34 & 22 & $\begin{array}{l}\text { Koper, N., and F. Schmiegelow. 2007. Does management } \\
\text { for duck productivity affect songbird nesting } \\
\text { success? Journal of Wildlife Management 71:2249. }\end{array}$ \\
\hline $\begin{array}{l}\text { Ronningen \& } \\
\text { Skaggs }\end{array}$ & $\begin{array}{l}\text { Delta } \\
\text { Waterfowl, } \\
\text { Louisiana State } \\
\text { University }\end{array}$ & ND & 2015-2017 & 5 & 50 & $\begin{array}{l}\text { Skaggs, C.G. 2019. Effects of Oil and Gas Development } \\
\text { on Waterfowl Nesting Ecology in the Bakken } \\
\text { Formation of North Dakota. M.S. Thesis. Louisiana } \\
\text { State University and Agricultural and Mechanical } \\
\text { College. }\end{array}$ \\
\hline $\begin{array}{l}\text { Specht and other } \\
\text { single nest finds }\end{array}$ & $\begin{array}{l}\text { University of } \\
\text { MN, USFWS, } \\
\text { USGS, RMBO, } \\
\text { DU }\end{array}$ & ND & 2014-2016 & 11 & 4 & $\begin{array}{l}\text { Specht, H.M. 2018. Habitat use and reproductive } \\
\text { success of waterbirds in the human-dominated } \\
\text { landscape of North America's prairies: Using } \\
\text { sparse data to inform management. PhD } \\
\text { Dissertation. Conservation Sciences. University of } \\
\text { Minnesota, St. Paul, USA. }\end{array}$ \\
\hline TOTAL & & & & 354 & 709 & \\
\hline
\end{tabular}

2 | Appendix materials to accompany: Specht, H.M., V. St-Louis, C. Gratto-Trevor, N. Koper, C. Skaggs, T. Ronningen and T.W. Arnold. 2019. Habitat selection and nest survival in two Great Plains shorebirds. Avian Conservation and Ecology. 
Table A1.2 Species-specific nest survival estimates from a nest survival model that included only random intercept effects for the year and study plot corresponding to each nest record. Each line represents null model (no covariate) analysis of a different subset or treatment of the nest survival data;

subsets/treatments vary by whether nest age (expected hatch date) was estimated and by the timing of nest fate assessment visits relative to the estimated hatch date or the previous visit. Analyzed data subsets included nest records for which specific location was not known (study site is always designated) - unknown location nests were excluded from final analyses, such that estimates presented here differ slightly from those presented in results. The second row (model B) represents the data subset/treatment most similar to common shorebird nest survival studies and was considered a reference for comparisons of other models.

\begin{tabular}{|c|c|c|c|c|c|c|c|}
\hline Model & $\begin{array}{l}\text { Nest age } \\
\text { estimated }\end{array}$ & $\begin{array}{l}\text { Timing of } \\
\text { fate visit }\end{array}$ & $\begin{array}{l}\text { Number } \\
\text { of nests/ } \\
\text { with } \\
\text { location }\end{array}$ & $\begin{array}{l}\text { Estimated } \\
\text { Daily Survival } \\
\text { Rate Marbled } \\
\text { Godwit }\end{array}$ & $\begin{array}{l}\text { Estimated } \\
\text { Daily } \\
\text { Survival } \\
\text { Rate Willet }\end{array}$ & $\begin{array}{l}\text { Nest survival } \\
\text { marbled } \\
\text { godwit ( } 28 \\
\text { days) }\end{array}$ & $\begin{array}{l}\text { Nest } \\
\text { survival } \\
\text { marbled } \\
\text { godwit (27 } \\
\text { days) }\end{array}$ \\
\hline A & Yes & $\begin{array}{l}\text { Fated within } \\
4 \text { days or } \\
\text { truncated } \\
\text { (95) }\end{array}$ & $602 / 569$ & $0.976(0.005)$ & $0.978(0.005)$ & $0.512(0.077)$ & $0.548(0.067)$ \\
\hline B & Yes & $\begin{array}{l}\text { Fated within } \\
7 \text { days or } \\
\text { truncated } \\
\text { (47) }\end{array}$ & $602 / 569$ & $0.980(0.004)$ & $0.976(0.005)$ & $0.569(0.071)$ & $0.525(0.067)$ \\
\hline C & Yes & $\begin{array}{l}\text { No limits, no } \\
\text { truncation }\end{array}$ & $602 / 569$ & $0.985(0.003)$ & $0.972(0.005)$ & $0.650(0.061)$ & $0.475(0.065)$ \\
\hline D & No & $\begin{array}{l}\text { Fated within } \\
7 \text { days of } \\
\text { previous visit } \\
\text { or truncated } \\
(307)\end{array}$ & $759 / 685$ & $0.998(0.002)$ & $0.997(0.002)$ & $0.939(0.041)$ & $0.932(0.046)$ \\
\hline E & No & $\begin{array}{l}\text { Fated within } \\
14 \text { days of } \\
\text { previous visit } \\
\text { or truncated } \\
(307)\end{array}$ & $759 / 685$ & $0.989(0.005)$ & $0.988(0.006)$ & $0.732(0.102)$ & $0.723(0.102)$ \\
\hline $\mathbf{F}$ & No & $\begin{array}{l}\text { No } \\
\text { constraint }\end{array}$ & $759 / 685$ & $0.967(0.013)$ & $0.958(0.016)$ & $0.418(0.132)$ & $0.340(0.130)$ \\
\hline G & No & $\begin{array}{l}\text { Only nests } \\
\text { that were } \\
\text { fated }>7 \\
\text { days after } \\
\text { hatching or } \\
\text { of unknown } \\
\text { age, i.e. only } \\
\text { the worst } \\
\text { data }\end{array}$ & 307 & $0.913(0.046)$ & $0.870(0.063)$ & $0.139(0.124)$ & $0.064(0.078)$ \\
\hline
\end{tabular}

3 | Appendix materials to accompany: Specht, H.M., V. St-Louis, C. Gratto-Trevor, N. Koper, C. Skaggs, T. Ronningen and T.W. Arnold. 2019. Habitat selection and nest survival in two Great Plains shorebirds. Avian Conservation and Ecology. 


\section{Model Formulations and Code}

\section{When does nesting occur?}

Model for examining whether nest initiation has shifted earlier in the season over the study period, as might be predicted by warming early season temperatures due to climate change?

initiation $_{i}=B_{0}+b_{1} *$ Latitude $_{i} B_{2} *$ Year $_{i} \quad$ eqn A1.1

for each nest, i, that included location and nest initiation data, where initiation and latitude were continuous variables that were standardized across the dataset. If nest initiation occurred earlier over the years, we would expect a negative relationship between initiation and year in addition to variation accounted for by latitude.

Model for examining whether nests were initiated later at higher latitudes (within years)?

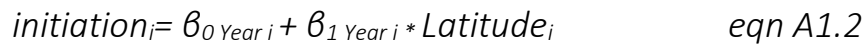

for each nest, i, that included location and nest initiation data, where initiation and latitude were continuous variables that were standardized across the dataset. If nest initiation occurred earlier at higher latitudes, we would expect a positive relationships between latitude and initiation within years.

\section{Do species exhibit selection for broad-scale breeding habitat characteristics?}

R, JagsUI code for Discrete Choice Habitat Selection Model for each species

This approach is well described in Harju et al. (2011), Appendix 2.

Harju, S.M., M.R. Dzialak, R.G. Osborn, L.D. Hayden-Wing \& J.B. Winstead. 2011. Conservation planning using resource selection models: altered selection in the presence of human activity changes spatial prediction of resource use. Animal Conservation 14: 502-511.

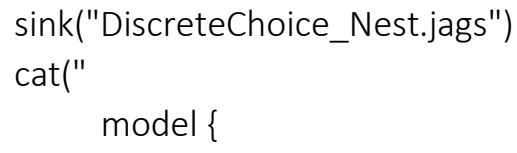

\# Priors on coefficients loop across nest ID for random slope coefficient values by nest ID since each set of available points was drawn to correspond to a specific nest record.

4 | Appendix materials to accompany: Specht, H.M., V. St-Louis, C. Gratto-Trevor, N. Koper, C. Skaggs, T. Ronningen and T.W. Arnold. 2019. Habitat selection and nest survival in two Great Plains shorebirds. Avian Conservation and Ecology. 
Do species exhibit selection for broad-scale breeding habitat characteristics? Model code, continued.

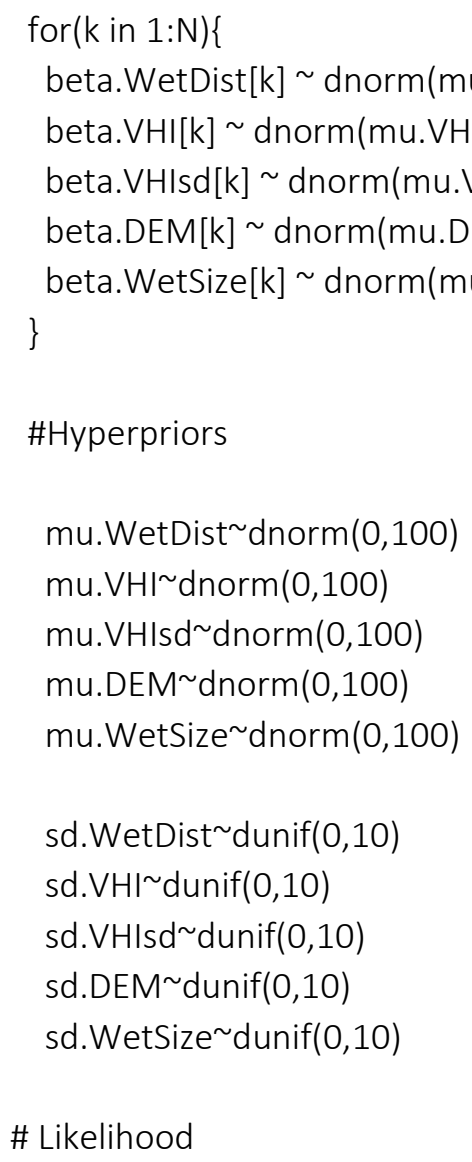

$$
Y\left[\left(\left((i-1)^{*} J\right)+1\right):(((i-1) * J)+J)\right] \sim \operatorname{dmulti}(p[i, 1: J], 1)
$$

\#dmulti is described by two parameters: $\mathrm{n}$ (an integer), and pi (a single dimensional vector that sums to 1 ).

$\# p$ is a matrix with $\mathrm{N}$ rows and $\mathrm{J}=6$ columns.

for(j in 1:J)\{ \# loop across J=6 choices within set of 1 used, 5 (case-specific) available $p[i, j]<-e[i, j] / \operatorname{sum}(e[i]$,$) \quad \# Conditional likelihood$

5 | Appendix materials to accompany: Specht, H.M., V. St-Louis, C. Gratto-Trevor, N. Koper, C. Skaggs, T. Ronningen and T.W. Arnold. 2019. Habitat selection and nest survival in two Great Plains shorebirds. Avian Conservation and Ecology. 
Do species exhibit selection for broad-scale breeding habitat characteristics? Model code, continued.

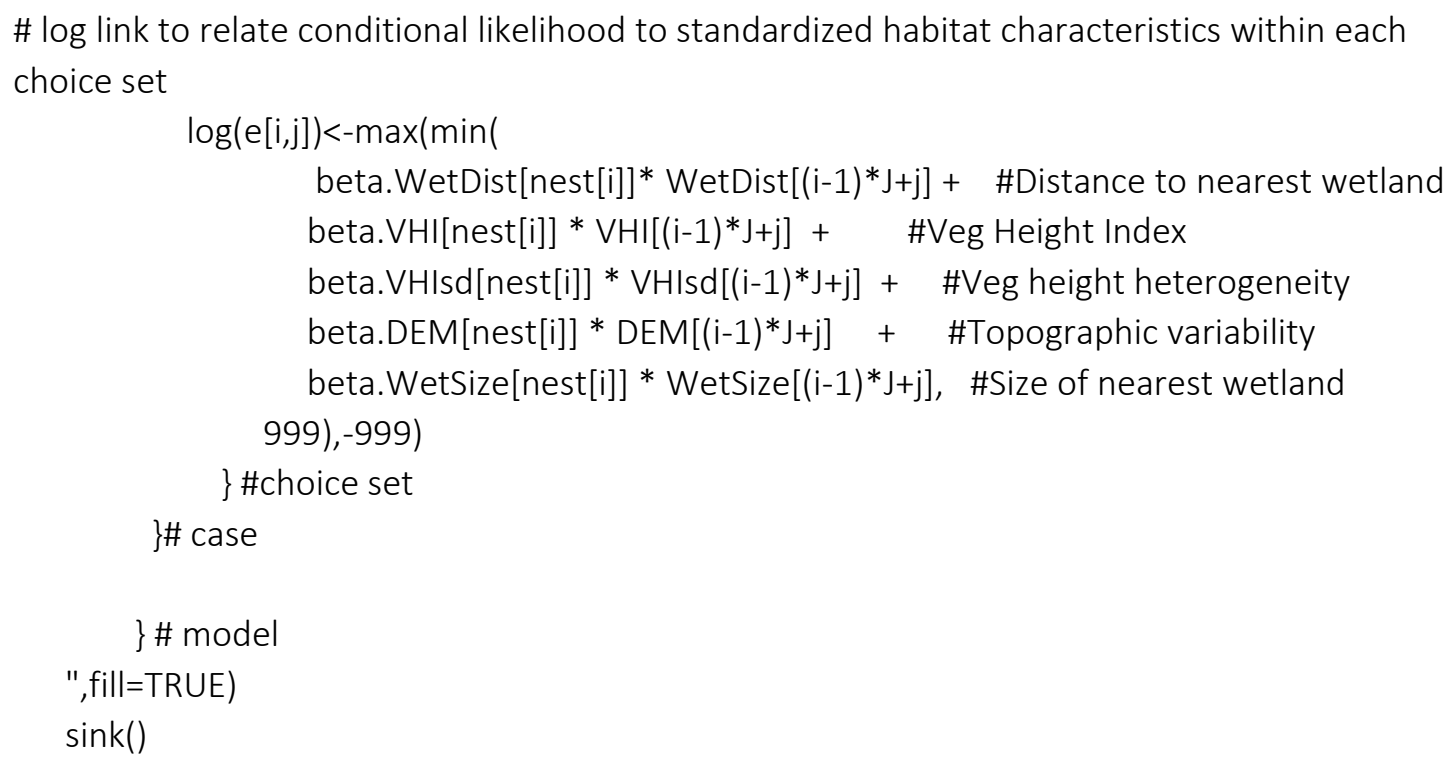

\section{Do Willets and Marbled Godwits differ in their habitat use?}

$\mathrm{R}$, JagsUl code for habitat use comparisons of characteristics around nests and at a broader scale.

Comparisons are modeled with a logit link where the response variable differentiates species (Marbled Godwit was designated as 1 , Willet as 0 ) such that results are interpreted as Marbled Godwit habitat use relative to Willets.

Nests:

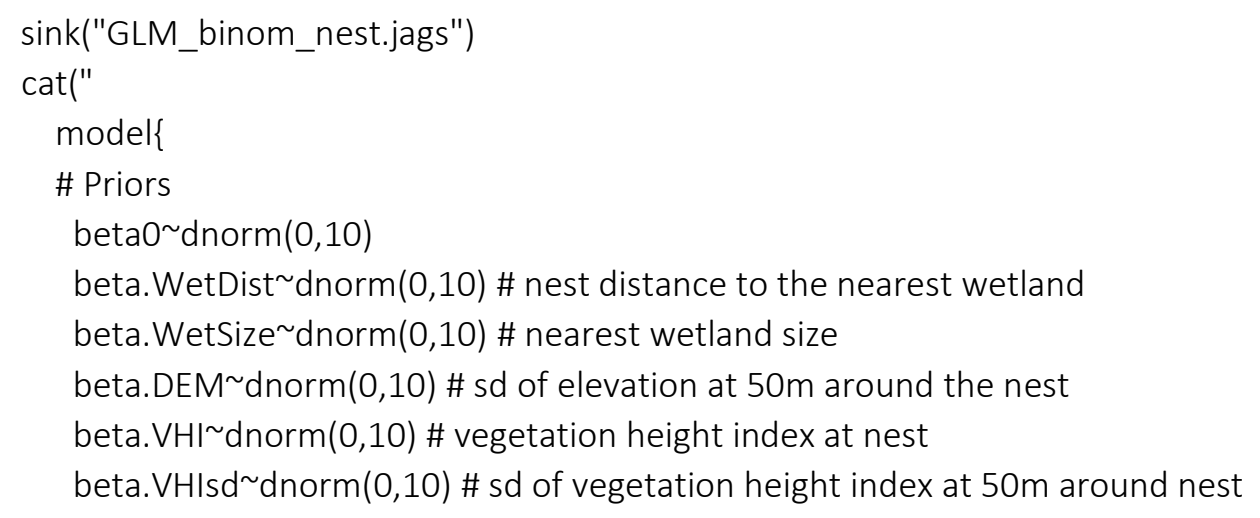

6 | Appendix materials to accompany: Specht, H.M., V. St-Louis, C. Gratto-Trevor, N. Koper, C. Skaggs, T. Ronningen and T.W. Arnold. 2019. Habitat selection and nest survival in two Great Plains shorebirds. Avian Conservation and Ecology. 
Do Willets and Marbled Godwits differ in their habitat use? Model code, continued.

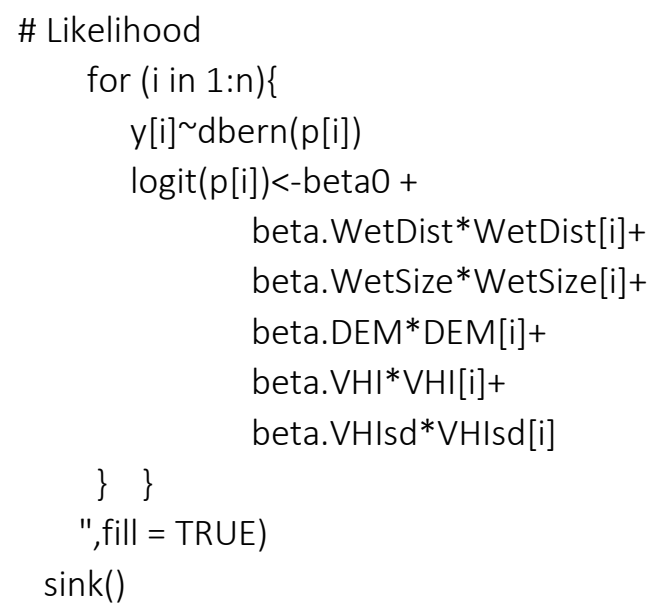

\section{Broader scale ( $375 \mathrm{~m}$ around a nest):}

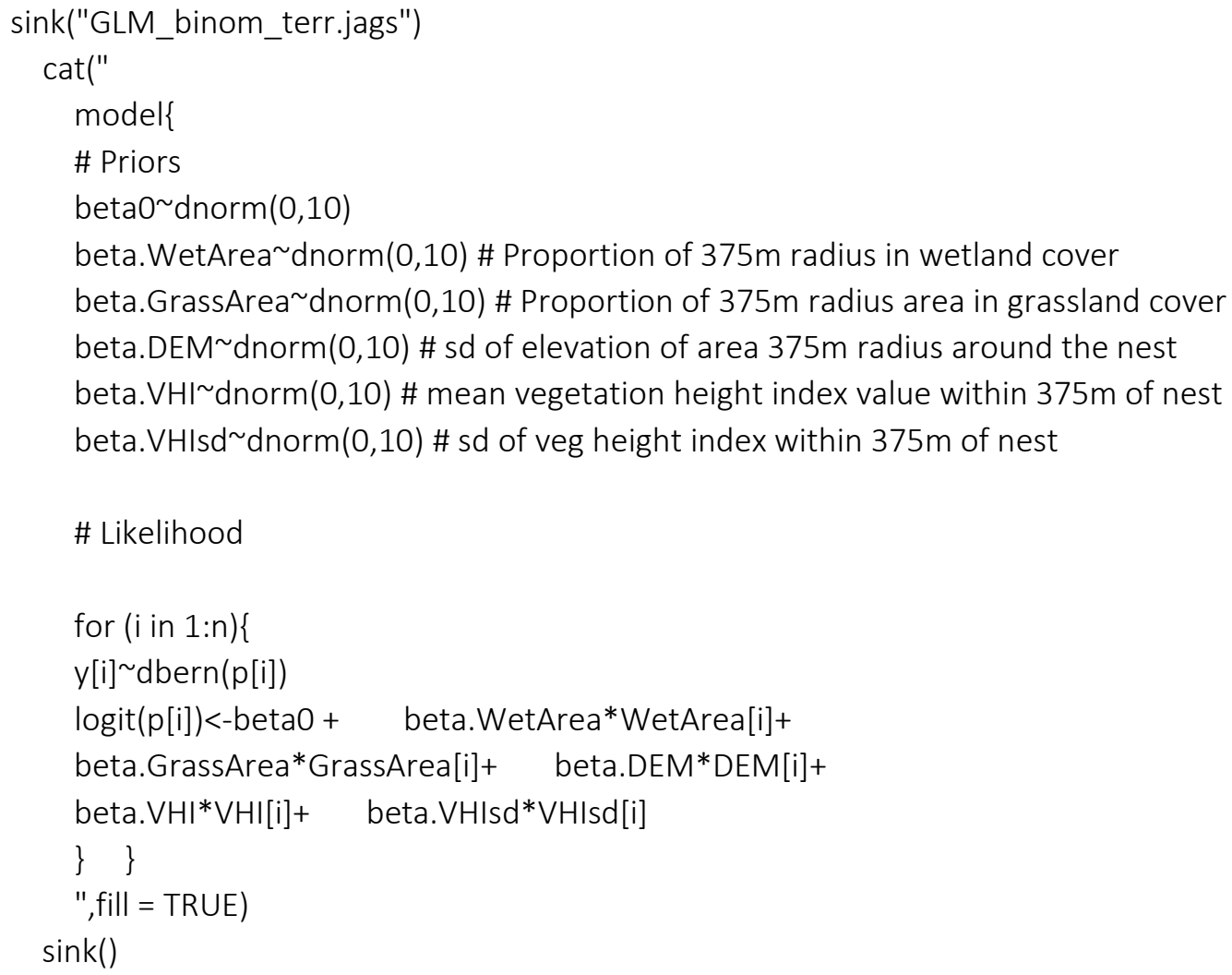

7 | Appendix materials to accompany: Specht, H.M., V. St-Louis, C. Gratto-Trevor, N. Koper, C. Skaggs, T. Ronningen and T.W. Arnold. 2019. Habitat selection and nest survival in two Great Plains shorebirds. Avian Conservation and Ecology. 


\section{How do habitat characteristics and temporal variation in predator and prey communities influence}

nest survival?

\section{R, JagsUl code for Null Bayesian Nest Survival model}

\# Jags version

sink("dsr.jags.null")

cat("

model \{

\#Priors===============

\#Random Effects

for ( $r$ in 1:nYears)\{

eta.Study_Yr[r] dnorm(0, tau.Study_Yr) \# Prior for random effect of year

\}

sigma.Study_Yr $\sim$ dunif $(0,5)$ \#residual standard deviation for rand effect of year

tau.Study_Yr <- pow(sigma.Study_Yr, -2) \#precision param for rand effect of year

for (s in 1:nPlot)\{

eta.Study_Plot[s] dnorm(0, tau.Study_Plot) \# Prior for random effect of Plot

\}

sigma.Study_Plot $\sim$ dunif $(0,5)$ \#residual standard deviation for rand effect of plot

tau.Study_Plot <- pow(sigma.Study_Plot, -2) \#precision param for rand effect of plot

\#Fixed Effects================

$\mathrm{dsr} \sim \operatorname{dunif}(0,1)$ \# Prior for daily nest survival rate

beta.mu <- logit(dsr) \# logit prior for intercept

\# Likelihood===================

for (i in 1:no.nests)\{

for ( $\mathrm{j}$ in found[i]:penult[i])\{

logit(S1[i,j]) <- beta.mu + eta.Study_Yr[Study_Year[i]] + eta.Study_Plot[Study_Plot[i]]

+ beta.spp * spp[i]

\} \# replace dsr with linear function of nest covariates [i], age [i,j]

8 | Appendix materials to accompany: Specht, H.M., V. St-Louis, C. Gratto-Trevor, N. Koper, C. Skaggs, T. Ronningen and T.W. Arnold. 2019. Habitat selection and nest survival in two Great Plains shorebirds. Avian Conservation and Ecology. 
How do habitat characteristics and temporal variation in predator and prey communities influence nest survival? Model code, continued.

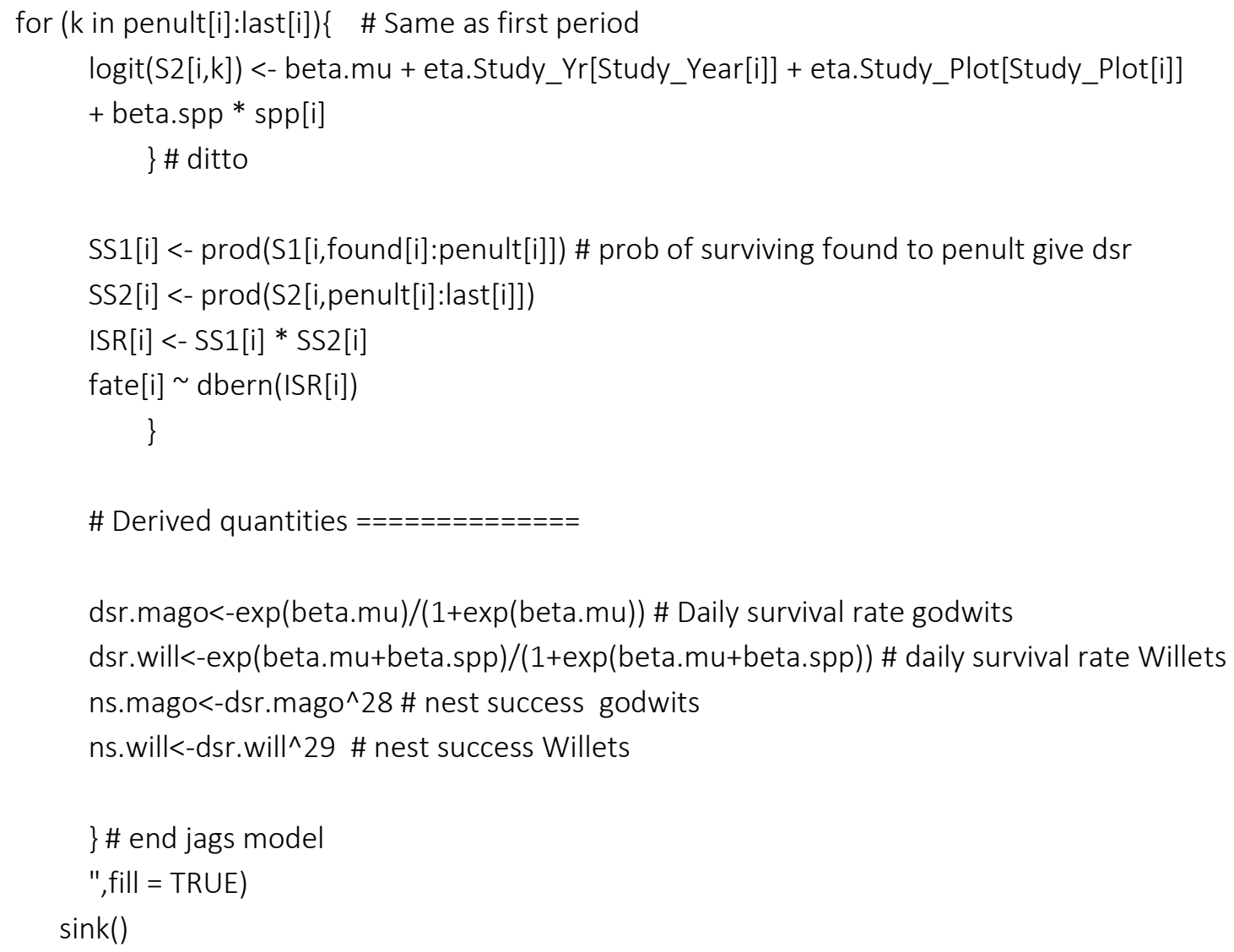

\section{R, JagsUl code for Full Bayesian Nest Survival model}

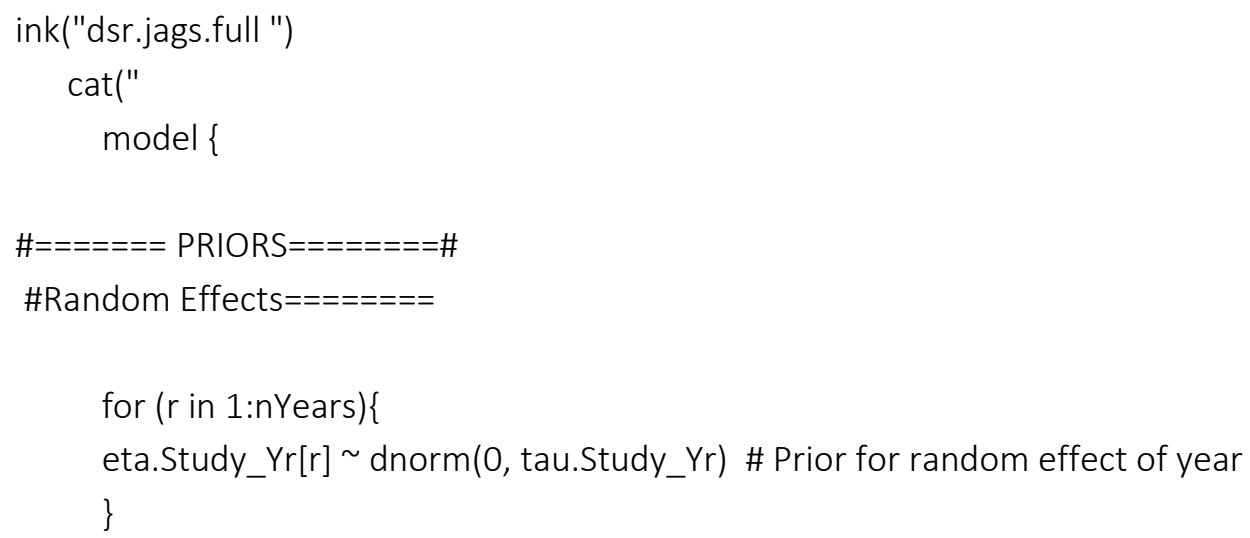

9 | Appendix materials to accompany: Specht, H.M., V. St-Louis, C. Gratto-Trevor, N. Koper, C. Skaggs, T. Ronningen and T.W. Arnold. 2019. Habitat selection and nest survival in two Great Plains shorebirds. Avian Conservation and Ecology. 
How do habitat characteristics and temporal variation in predator and prey communities influence nest survival? Model code, continued.

sigma.Study_Yr dunif $(0,5)$ \#residual standard deviation for random effect of year

tau.Study_Yr <- pow(sigma.Study_Yr, -2) \#precision specification for random effect of year

for (s in 1:nPlot)\{

eta.Study_Plot[s] dnorm(0, tau.Study_Plot) \# Prior for random effect of PI

\}

sigma.Study_Plot dunif $(0,5)$ \#residual standard deviation for random effect of study plot tau.Study_Plot <- pow(sigma.Study_Plot, -2) \#precision specification for random effect of study plot

\#Fixed Effects ========

dsr dunif $(0,1)$

beta.mu<-logit(dsr) \# Overall mean/ intercept

\#beta.year dnorm $(0,0.3)$ \#prior for year -- when not included as random effect

beta.age dnorm $(0,0.3)$ \#prior for drought

beta.init $\sim$ dnorm $(0,0.3)$ \#prior date of nest initiation

beta.init2 dnorm $(0,0.3)$ \#prior date of nest initiation

\#beta.MAGO dnorm $(0,0.3)$ \# Prior for godwit

\#beta.WILL dnorm $(0,0.3)$ \#prior for willet

beta.Lat $\sim$ dnorm $(0,0.3)$ \#prior for latitude

beta.BPUP dnorm $(0,0.3)$ \# prior for dabbling duck density

beta.SEOW dnorm $(0,0.3)$ \# prior for SEOW density

beta.CDen.MAGO dnorm $(0,0.3)$ \# prior for SEOW density

beta.CDen.WILL dnorm $(0,0.3)$ \# prior for SEOW density

\# Vegetation variables

beta.VHI.N.WILL dnorm $(0,0.3)$ \# prior for veg height index

beta.VHI.N.MAGO dnorm $(0,0.3)$ \# prior for veg height index

beta.VHI.sd dnorm $(0,0.3)$ \# prior for veg height index

beta.Grass $1000 \sim$ dnorm $(0,0.3)$ \# prior for relative grass cover at territory scale

beta.GrassI.MAGO dnorm(0,0.3) \# prior for location of nest in native grass

beta.GrassI.WILL dnorm $(0,0.3)$ \# prior for location of nest in native grass

10 | Appendix materials to accompany: Specht, H.M., V. St-Louis, C. Gratto-Trevor, N. Koper, C. Skaggs, T. Ronningen and T.W. Arnold. 2019. Habitat selection and nest survival in two Great Plains shorebirds. Avian Conservation and Ecology. 
How do habitat characteristics and temporal variation in predator and prey communities influence nest survival? Model code, continued.

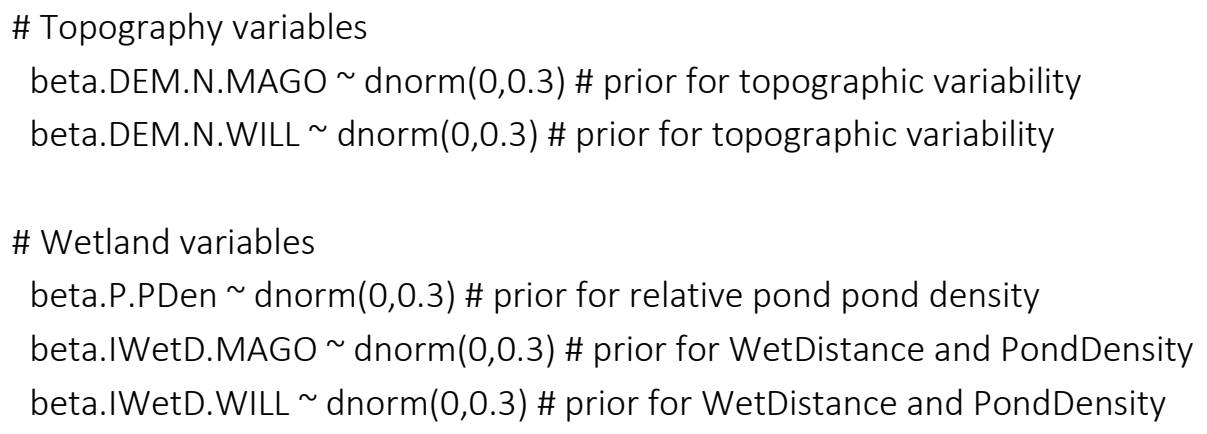

\# Likelihood:

for (i in 1:no.nests) \{ \# For each nest for ( $j$ in found[i]:penult[i])\{ \# from the day the nest was found to when it was last seen active

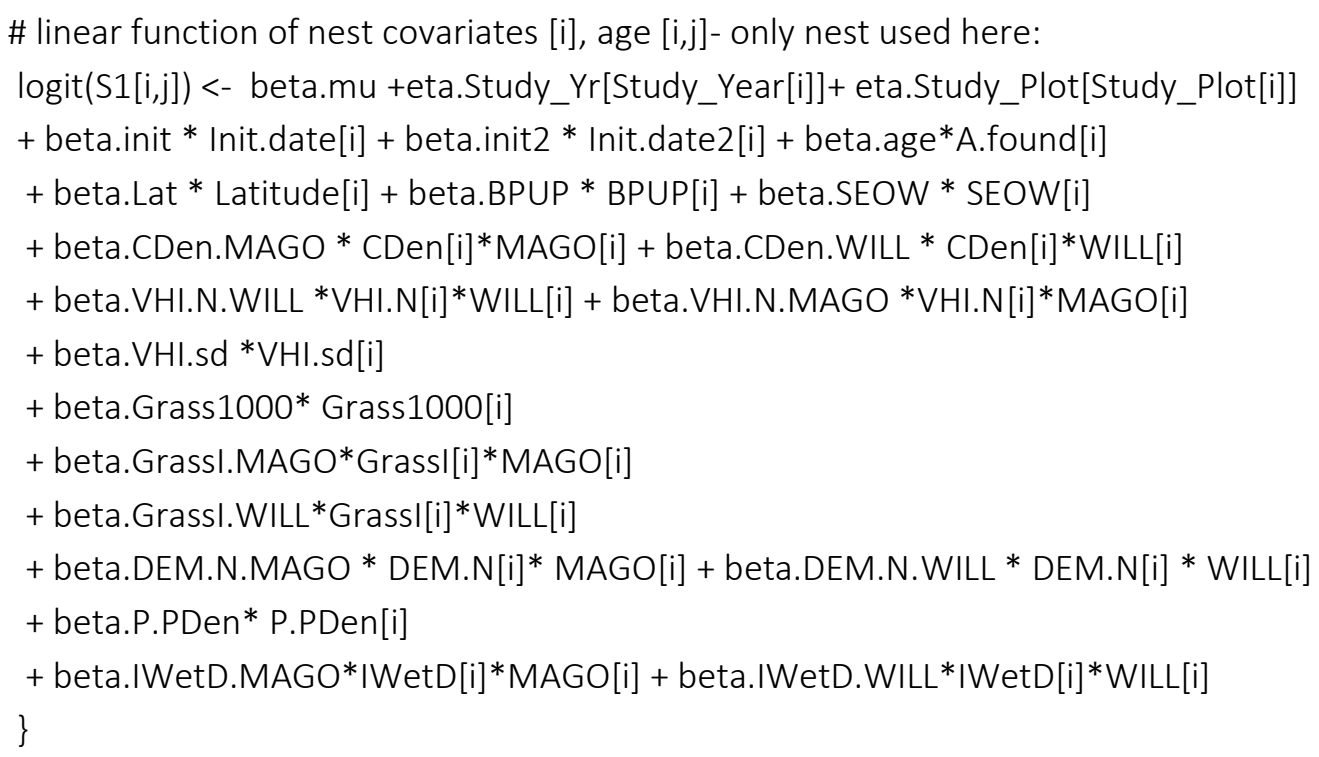

11 | Appendix materials to accompany: Specht, H.M., V. St-Louis, C. Gratto-Trevor, N. Koper, C. Skaggs, T. Ronningen and T.W. Arnold. 2019. Habitat selection and nest survival in two Great Plains shorebirds. Avian Conservation and Ecology. 
How do habitat characteristics and temporal variation in predator and prey communities influence nest survival? Model code, continued.

for ( $k$ in penult[i]:last[i])\{ \# from the day the nest was last seen active until the earlier of fate or expected hatch date

\# linear function of nest covariates [i], age [i,j]- SAME AS ABOVE. However, we didn't include day specific covariates in our model, just nest specific.

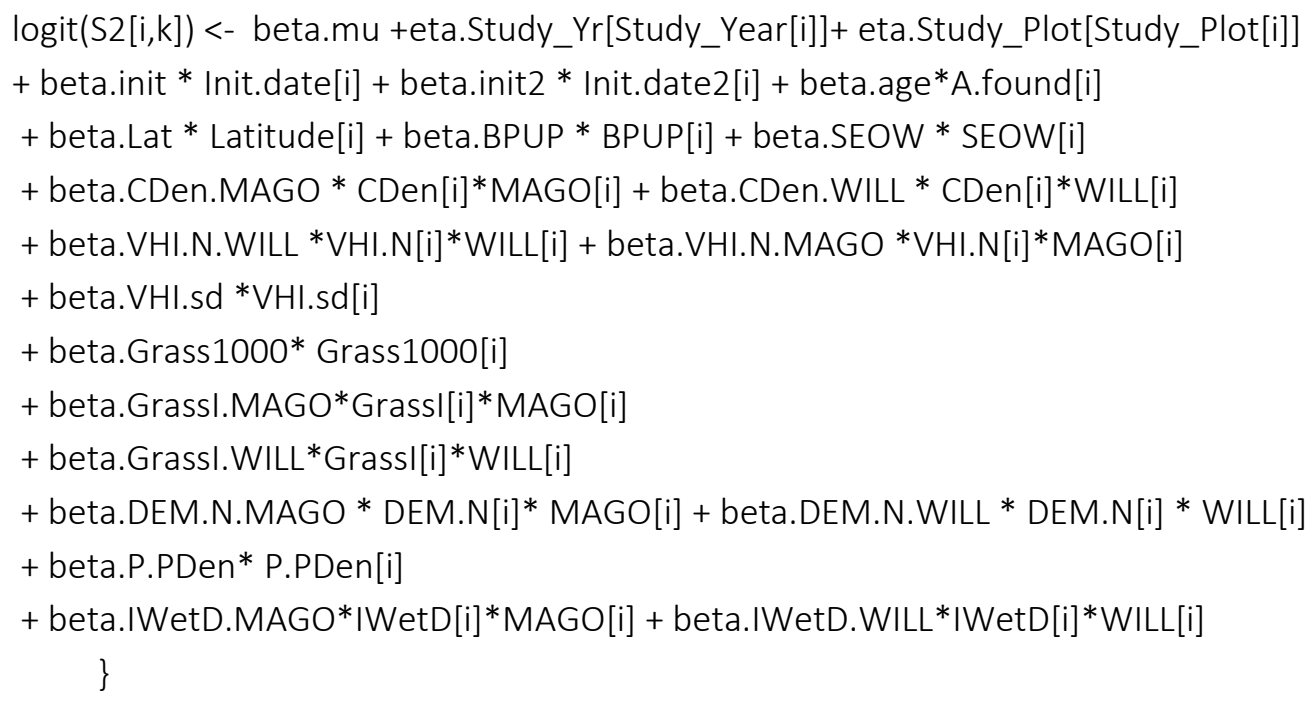

\# Specify relationships between S1, S2 and DSR:

SS1[i] <- $\operatorname{prod}(\mathrm{S} 1[i$, found[i]:penult[i]]) \# prob of surviving found to penult give dsr

SS2 [i] <- $\operatorname{prod}(S 2[i$, penult[i]:last[i]])

ISR[i] <- SS1[i] * SS2[i]

fate[i] dbern(ISR[i])

\}\# End likelihood

\}\# end jags model

", fill = TRUE)

$\operatorname{sink}()$

12 | Appendix materials to accompany: Specht, H.M., V. St-Louis, C. Gratto-Trevor, N. Koper, C. Skaggs, T. Ronningen and T.W. Arnold. 2019. Habitat selection and nest survival in two Great Plains shorebirds. Avian Conservation and Ecology. 